FABRÍCIO RODRIGO COSTA

\title{
A RELATIVIZAÇÃO DA SOBERANIA NO DIREITO INTERNACIONAL PÚBLICO
}

Tese de Doutorado

Orientadora: Professora Associada Dra.Cláudia Perrone-Moisés

Universidade de São Paulo

Faculdade de Direito

São Paulo

2020 

FABRÍCIO RODRIGO COSTA

\section{A RELATIVIZAÇÃO DA SOBERANIA NO DIREITO INTERNACIONAL PÚBLICO}

Tese apresentada à Banca Examinadora do Programa de Pós-Graduação em Direito da Faculdade de Direito da Universidade de São Paulo, como exigência parcial para a obtenção do título de Doutor em Direito, na área de concentração do Departamento de Direito Internacional e Comparado, sob orientação da Professora Associada Dra. Cláudia Perrone-Moisés.

Universidade de São Paulo

Faculdade de Direito

São Paulo - SP 
Ficha catalográfica

COSTA, Fabrício Rodrigo.

A relativização da soberania no direito internacional público / Fabrício Rodrigo Costa ; orientadora Cláudia Perrone-Moisés. São Paulo, 2020.

$371 \mathrm{f}$.

Tese (Doutorado)- Faculdade de Direito da Universidade de São Paulo. Departamento de Direito Internacional e Comparado. Área de Concentração: Direito Internacional e Comparado.

1. Direito Internacional. 2. História do Direito Internacional. 3. Filosofia do Direito. 4. Direito do Estado. 5. Filosofia Política. 6. Ciência Política. 7. Geografia Política. 8. Geopolítica. 9. Relações Internacionais. 10. Física. 


\section{AGRADECIMENTOS}

Pesquisar temas relativos aos problemas da humanidade torna-se uma honra, quando se pode compartilhar, desenvolver e aprofundar saberes com base em uma rede de pesquisadores humanistas que alertam para a necessidade de ser atentar para as condições humanas em um mundo repleto de estados-nações, administrados por uma burocracia quase onisciente e onipotente no cotidiano das pessoas. Nesse sentido, pela coragem, resiliência e vanguardismo, meus mais sinceros agradecimentos aos professores do departamento de Direito Internacional e Comparado e, em especial, à minha orientadora Cláudia Perrone-Moisés, por manterem uma trilha aberta com respeito ao estudo do direito internacional dos direitos humanos: fundamentação, elaboração e garantia.

Não obstante o processo de pesquisa seja um ato mais solitário do que comunal, os momentos de troca, avaliação e reavaliação das coordenadas são fundamentais para a correção de rumos nas tormentosas possibilidades relativas às escolhas temáticas $\mathrm{e}$ metológicas de linha de pesquisa tão abrangente quanto sensível. Diante dessa conjuntura, para que esse trabalho pudesse ter tido o bom augúrio de finalizar em porto seguro, expresso meus mais honestos e corretos sentimentos à banca de qualificação pela fineza, delicadeza e respeito no trato para comigo. Apoiado em ombros de gigantes, consegui visualizar um pouco mais adiante no horizonte sem fim relativo ao ser humano e sua condiçãojurídica em meio a uma sociedade de estados.

Gratidão àqueles amigos que fiz pelos livrose pela vida, cujo apoio em determinadas circunstâncias foram determinantes tanto pelas escolhas temáticas quanto pela lembrançada responsabilidade de se produzir conhecimento quepossibilite ampliar o entendimento da vida em sociedade em um único espaço. Em particular, dedico uma linha à minha amiga, musa, companheira e, sobretudo, ouvidora, que, com paciência e dedicação, contribuiu para diminuir os ruídos e gargalos textuais: Marie Felice Weinberg.

Por fim, para sobreviver ao cotidiano, cuja realidade e necessidades se impõem, reconheço e honro em público os esforços sem medida de meus familiares, ancestrais distantes e imediatos, em particular, meu pai João Cândido Costa e minha mãe Rosana de Fátima Almeida Pimentel Costa, pelos exemplos de disciplina, dedicação, comprometimento, fortaleza, resiliência, compaixão e entrega. Sem eles, fatalmente, o capitão desse navio, chamado tese de doutorado, teria naufragado ou caído doente na imensidão do mar salgado de uma pesquisa sem fins lucrativos, mas com a intenção de ser mais um ponto de apoio para a compreensão de nossa condição humana. 

A todas as pessoas que sofreram, sofrem ou sofrerão do arbítrio do Estado e de seu corpo burocrático e mercantil,: Seu sofrimento não foi, não é e nunca será em vão, para as causas da justiça, da verdade e da dignidade humana. 



\section{RESUMO}

Trata-se de uma pesquisa histórica do direito internacional em que se analisa a gênese do estado, da soberania, dos direitos fundamentais, das nações por meio do mapeamento da desintegração da Respublica Christianana Idade Moderna e da desagregação do sistema internacional de estados-nações na pós-modernidade. Por meio da contemplação desses fenômenos históricos, buscamos mapear a constituição da ordem jurídica clássica, calcada no estado, e os fatores que causaram as transformações dessa ordem em relação ao direito internacional. Para tanto, procuramos responder as seguintes indagações i) O que se entende por soberania estatal? (ii) Quais são suas características e limites? (iii) Qual é o processo que permitiu a relativização da soberania estatal no mundo contemporâneo?

Palavras-chaves: Direito Internacional; Soberania; Modelo Euclidiano de Ordem Jurídica; Fontes do Direito; Internacionalização da Quarta Marca da Soberania; Coexistência; Cooperação; Organização Internacional; Relativização da Soberania; Internacionalização dos Direitos Fundamentais; Indivíduo; Responsabilidade Individual; Lógica de Lótus; Lógica de Nuremberg; Crimes Internacionais dos Direitos Humanos.

COSTA, Fabrício Rodrigo. A relativização da soberania no direito internacional público. 2020. 371 f. Doutorado - Faculdade de Direito, Universidade de São Paulo, 2020. 



\begin{abstract}
It is a historical recherche on international law in which it is analyzed the genesis of the state, of sovereignty, of fundamental rights, of nations through mapping the disintegration of the Respublic Christiana in the Modern Age and the international system of the nationstate in the Post-Modern Age. By mapping these historical phenomena, we seek to map the constitution of the classic legal order, based on the state, and the circumstances that caused transformations of such order concerning the international legal order. To achieve such a task, we look for answers regarding the following questions: (i) what is sovereignty? (ii) what are the features and the limitations of sovereignty? (iii) what is the process that allowed the relativization of state sovereignty in the contemporary world?
\end{abstract}

Keywords: International Law; Sovereignty; Euclidean Legal Order Model; Sources of Law; Internationalization of the Fourth Mark of Sovereignty; Coexistence; Cooperation; International Organization; Individual; Individual Liability; Relativization of Sovereignty; Logic of Lotus; Logic of Nuremberg; International Crimes of Human Rights.

COSTA, Fabrício Rodrigo.The Relativization of Sovereignty in International Public Law. 2020. 371 pages. Doctorate - Faculty of Law, University of São Paulo, 2020. 



\section{RÉSUMÉ}

Il s'agit d'une recherche historique du droit international dans laquelle on analise la genèse de l'État, de la souveraineté, des droits fondamentaux, des nations à travers la configuration de la désagrégation de la Respublic Christiana à l'époque moderne et du système de l’État-nation à l'époque post-moderne. Par la cartographie de phénomènes historiques, on aura pour but déterminer la constitution de l'ordre juridique classique, fondé sur l'État, et les circonstances qui sont à l'origine des transformations de cet ordre là par rapport l'ordre juridique internationale. Pour bien mener cette tâche, on cherche pour répondre les questions suivantes: (i) quelle est la souveraineté? (ii) quelles sont les caractéristiques et les limitations de la souveraineté? (iii) quel est le processus qui a permis la relativisation de la souveraineté de l'État dans le monde contemporain?

Mots-clefs: Droit International; Souveraineté; Modèle Euclidien d'Ordre Juridique; Sources du Droit; Internationalisation de la Quatrième Marque de la Soveraineté; Coexistence; Coopération; Organisation Internationale; Individu; Responsabilité Individuelle; Relativisation de la Soveraineté; Logique de Lotus; Logique de Nuremberg; Crimes Internationaux des Droits de 1’Homme.

COSTA, Fabrício Rodrigo. La Relativisation de la Souveraineté en Droit Public International. 2020. 371 pages. Doctorat - Faculté de Droit, Université de São Paulo, 2020. 



\section{SUMÁRIO}

INTRODUÇÃO

1 DOUTRINADORES DO ESTADO E DA SOBERANIA ..................11

1.1 Nicolau Maquiavel e o stato: entre a inovação e a fundação .............11

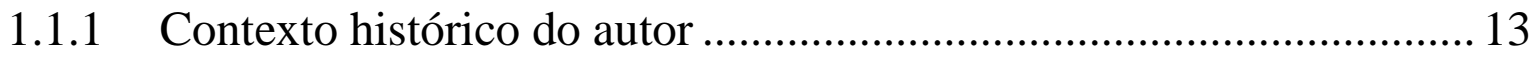



1.1.3 Um autor maquiavélico a serviço do absolutismo?............................ 30

1.2 Jean Bodin e a soberania absoluta e divina....................................52

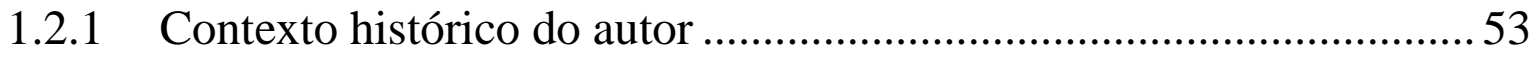



1.2.3 A distorção da soberania divina entre o absoluto e a arbitrariedade.. 68

1.3 Hugo Grócio entre o estado territorial e a soberania divisível: a liberdade dos mares e o direito da guerra e da paz na sociedade



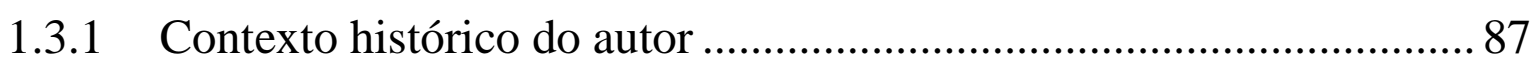

1.3.2 Hugo Grócio: vida e obra ................................................................ 98

1.3.3 O Direito da guerra e da paz (1625) e da paternidade do direito internacional 
1.4 Thomas Hobbes: a sincronização do homem artificial Machina Machinarum entre as soberanias nacional e popular no estado de natureza 133

1.4.1 Thomas Hobbes: vida e obra em seu contexto histórico 137

1.4.2 A irrevogabilidade da soberania e os limites jurídicos da pessoa artificial. 163

1.4.3 O limite de fato do homem artificial machina machinarum com seus pares na potencialidade do estado de natureza. 204

2 A RELATIVIZAÇÃO DA SOBERANIA NO DIREITO INTERNACIONAL: DA LÓGICA DE LÓTUS À LÓGICA DE NUREMBERG 235

2.1 A lógica de Lótus e a soberania territorial 248

2.2 Lógica de Nuremberg e a relativização da soberania no direito

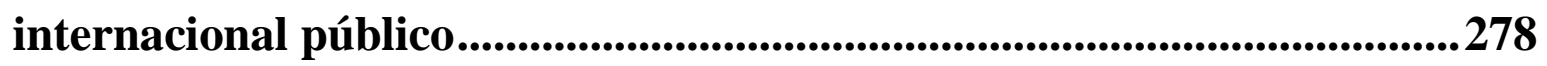

EPÍlOGO. A SOBERANIA NO DIREITO INTERNACIONAL PÓS-



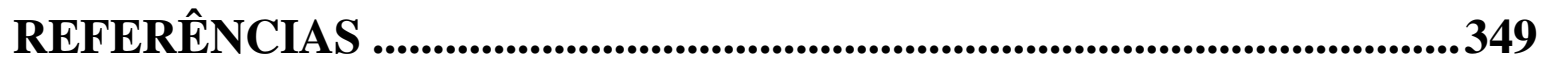

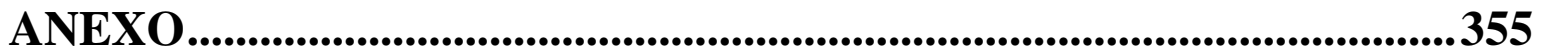




\section{INTRODUÇÃO}

Ao mapear a forma como a soberania estatal tem sido gradualmente relativizada em favor da penetração do indivíduo na esfera do direito internacional, buscamos apontar para o deslocamento do centro de gravidade da matéria, por meio de análises doutrinárias, jurisprudenciais e históricas com relação aos fatos e às fontes do direito internacional no tratamento de um componente muito específico do estado, qual seja o território, noção fundamental do direito internacional, sede da independência.

Logo na primeira frase da nota preliminar de seu ensaio sobre o fundamento da ordem jurídica, Goffredo Telles Junior ensina que "o advento do ser humano se prende à evolução da matéria cósmica."1 Diante dessa premissa, e com base no território e sua dimensão humana, procuraremos apontar para o peso que o direito internacional tem conferido à pessoa humana, de modo a contribuir para equilibrar o jogo de força entre estado territorial e condição humano nos estados e entre os estados. A evolução de um sistema institucional e normativo, criado entre estados, mas cuja finalidade seja o ser humano depende da distribuição de normas, princípios, instituições e valores que busquem (i) relativizar o primado da competência territorial sobre a competência pessoal do estado e (ii) delimitar a extensão do domínio reservado dos estados.

Aparentemente contraditório à humanização do direito internacional, optamos em dar destaque ao mapeamento do tratamento legal do título jurídico sobre o território, pois, ao longo de toda a tese, nos debruçaremos sobre a regra no direito internacional, qual seja a territorialidade, como forma de podermos avaliar alguns pontos de inflexão relativos à exceção: a extraterritorialidade.

Expressão da culturalidade humana, o nomear das coisas, por meio da criação de palavras, é a forma humana de apropriação e desalienação do mundo ao qual, segundo Hannah Arendt e Celso Lafer, chegamos como noviços ou estrangeiros. ${ }^{2}$ A nominação do espaço implica a diferenciação cultural e a determinação de categorias jurídicas distintas para sua regulação, em que a relação entre espaço e poder sob as formas de soberania, de

${ }^{1}$ TELLES JUNIOR, Goffredo. Direito Quântico: ensaio sobre o fundamento da ordem jurídica.9. ed., São Paulo: Saraiva, 2014. p. 19.

${ }^{2}$ LAFER, Celso. Hannah Arendt: Pensamento, Persuasão e Poder. Rio de Janeiro: Paz e Terra, 1979. (Coleção O Mundo, hoje, v.35). p. 87. 
jurisdição, de domínio reservado e de competências territorialmente localizadas, fundam o espaço e o expandem, segundo a mentalidade histórica e cultural de cada época. ${ }^{3}$

Ensina Goffredo Telles que, como pressuposto de continuidade e de permanência, "toda existência tem por condição a estrutura" cuja natureza é a estabilidade, que depende de uma disposição ordenada de forças e de elementos que a constitui. E continua: "este é motivo pelo qual os gregos chamavam o universo de 'cosmos', palavra que significa ordem, e não o chamavam de 'caos', palavra que significa ausência de ordem." Nesse sentido, podemos definir ordem como a "disposição conveniente de seres, para a consecução de um fim comum", relacionando e fazendo dos múltiplos e diversos seres, "partes de um só todo, ou seja, partes de uma unidade", o que nos leva a poder definir ordem como "uma unidade feita do múltiplo." Dessa forma, fica claro que a ordem implica multiplicidade e unidade, calcada na "dominação da unidade sobre o múltiplo."

Compreendido como ordem, o sistema internacional decorre da soma de sistemas internos, dispostos lado a lado, tal qual o mapa político, e nele se inscreve o conjunto de princípios, de norma e de instituições. Como decorrência da validade e da efetividade com que a soberania estatal e a territorialidade norteiam a formulação e a operacionalização das instituições e normas internacionais, o sistema internacional permanece largamente territorializado e interestatal.

Por meio de análises das relações entre espaço e estado, onde se observa o exercício das jurisdições de um lado, e, de outro, entre soberania e território, em que se observam os fatos que geram títulos potenciais determinantes para o exercício da jurisdicional dos estados, buscaremos avaliar a magnitude pela qual o direito internacional tem conferido à distribuição de espaço entre estados para determinar a dimensão humana do território na ordem internacional estruturada na multiplicadade de países territorialmente delimitados e na unidade do planeta. Nesse sentido, como aponta Paulo Borba Casella, a expressão territorial da soberania dos estados exige adequação e redefinição, para que se possa avaliar a mutação mais relevante no direito internacional, no contexto pós-moderno, qual seja: a estruturação progressiva do sistema internacional de proteção dos direitos fundamentais. ${ }^{5}$

${ }^{3}$ CASELLA, Paulo Borba. Direito Internacional dos Espaços. São Paulo: Atlas, 2009. p. 891-909.

${ }^{4}$ TELLES JUNIOR, Goffredo. Direito Quântico: ensaio sobre o fundamento da ordem jurídica.9. ed., São Paulo: Saraiva, 2014. p. 190-9.

${ }^{5}$ CASELLA, Paulo Borba. Direito Internacional dos Espaços. São Paulo: Atlas, 2009. p. 829. 
Nesse caminho de afirmação da humanização do direito das gentes, em que se observa paulatina e crescente importância dos direitos humanos na estruturação da ordem jurídica no mundo contemporâneo, identificamos na tese de Guilherme Assis de Almeida a ideia de sacralidade do ser humano e sua projeção na missão civilizatória do direito internacional nos séculos XIX e XX. A sacralidade é uma forma antes de tudo usada na legitimação do domínio, seja da lei, do governo, do governante ou da ordem, e, ao Assis de Almeida localizá-la na pessoa humana, por meio de juízo reflexivo que oferece narrativa de sustentação desse valor tanto no domínio reservado do estado quanto, posteriormente, no direito internacional;observa-se grande inflexão da forma como a concepção tem sido operacionalizada nas relações e no direito internacional: de Deus para Roma, de Roma para o Rei, do Rei para a Lei. ${ }^{6}$

O que pretendemos demonstrar, com a tese da relativização da soberania no direito internacional, é a tensão permanente em torno da gradativa emergência de um novo sistema de referência fundado na existência do ser humano como sujeito de direito internacional em relação a um ordenamento classicamente estatal e territorializado (euclidiano).

Tributários do direito romano e da influência das ideias cristãs, a ordem jurídica internacional e o estado soberano apresentam relacionamento ambíguo, quando se trata do domínio da unidade sobre as múltiplas partes. O direito internacional é, em grande parte, decorrência de consentimento estatal por meio de convenção, pacto ou ato de escolha entre sujeitos que decidem instaurar e ser regido por uma ordem legal. ${ }^{7}$ Grosso modo, há duas concepções prevalentes sobre o direito internacional: (i) solidarista, cujo ponto de partida é o reconhecimento de uma comunidade internacional como valor e (ii) voluntarista, que apresenta o direito como produto da vontade do poder soberano de dois, de muitos e de todos os estados.

Para nós, essa tensão entre a parte soberana e o todo jurídico é um problema de ordem em que se apresenta um impasse com relação "à disposição conveniente de seres para a consecução de um fim comum". ${ }^{8}$ Identificamos que, quando o domínio da unidade é desobedecido pelas partes, essa desobediência põe em relevo o paradoxo da autoridade. Ao

\footnotetext{
6 ALMEIDA, Guilherme Assis de. A Proteção da Pessoa Humana no Direito Internacional: Conflitos Armados, Refugiados e Discriminação Racial. São Paulo: Editora CLA Cultural, 2018. p. 40/1.

${ }^{7}$ CASELLA, Paulo Borba. Direito Internacional dos Espaços. São Paulo: Atlas, 2009. p. 5.

8 TELLES JUNIOR, Goffredo. Direito Quântico: ensaio sobre o fundamento da ordem jurídica.9. ed., São Paulo: Saraiva, 2014. p. 211.
} 
cunhar esse termo, Paul Ricouer quis indicar "uma espécie de contradição não resolvida [...] ligada à dificuldade ou mesmo à impossibilidade de legitimar, em última instância, a autoridade," o que destaca o lado dissimétrico e hierárquico de uma noção que põe face a face aqueles que mandam e aqueles que obedecem. ${ }^{9}$ Quando acontece a deslegitimação da ordem, o paradoxo da autoridade se instala, de modo que, a desordem que se produz constitui a ordem que não é conveniente, "é a ordem que não queremos", "é a ordem que não nos convém", que está em desacordo entre a ordem existente na realidade e a nossa ideia de ordem. ${ }^{10}$

Para nós, a contradição não resolvida em torno da autoridade do direito internacional como única alternativa à solução imperial e hegemônica das relações interestatais tem relação (i) com a natureza anárquica do sistema internacional, resultado da divisão do poder entre unidades juridicamente iguais, mas com capacidades econômicas, militares e demográficas diferentes; (ii) com a problemática representação dos sujeitos de direito legitimados e com capacidade de iniciar um empreendimento, dominar uma necessidade e levar a cabo a finalidade comum da ordem.

Até o presente, a ideia de ordem internacional, com base na inter-relação entre estado, povo e minorias tem garantido a supremacia dos estados face aos seres humanos, o que nos leva a afirmar que a razão de estado e a soberania estatal têm conseguido levar ao fim o que lhes convém. Não obstante essa supremacia da soberania estatal como representante da ordem, a compreensão simbólica desse impasse na autoridade do direito internacional como representante da unidade da sociedade internacional tem bases nas contradições inerentes à disputa entre os poderes secular e espiritual, na regulação dos assuntos humanos. Mito fundacional ou não, simbólico dessas contradições não resolvidas relativas à obediência e à representação, é o episódio do "canto do galo" em que Cristo alerta, como um sinal da hora, Pedro sobre a negação de sua autoridade espiritual, quando o discípulo fosse questionado sobre existência do líder espiritual pelos soldados do império romano, representantes do poder secular. ${ }^{11}$

9 RICOEUR, Paul. O Justo 2: Justiça e Verdade e Outros Estudos. São Paulo: WMF Martins Fontes, 2008. p. 101.

${ }^{10}$ TELLES JUNIOR, Goffredo. Direito Quântico: ensaio sobre o fundamento da ordem jurídica. 9. ed., São Paulo: Saraiva, 2014. p. 199-200.

${ }^{11}$ Nota explicativa: a expressão "canto do galo", encontramos, com ligeiras variações, nos quatro Evangelhos (Mateus ["Jesus declarou: Em verdade te digo que esta noite, antes que o galo cante, me negarás três vezes! \{26,34\}; Marcos ["Disse-lhe Jesus: Em verdade te digo que hoje, esta noite, antes que o galo cante duas vezes, me negarás três vezes" $\{14,30\}$ ]; Lucas [ "Mas ele disse: Pedro eu te digo, (o) galo não cantará hoje sem que por três vezes tenhas negado conhecer-me." \{22,34\}]; João ["Jesus lhe responde: Darás a tua vida 
Observado da perspectiva das relações internacionais e como um limite de fato ao poder soberano, o paradoxo da autoridade pode ser apresentado sob a forma de questões que envolvem supremacia, poder e sobrevivência, e que dizem respeito ao dilema da segurança, dimensão incontornável do sistema internacional anárquico, em que inexiste uma autoridade superior aos estados que possa garantir a segurança coletiva. Na falta dessa autoridade, segundo o formulador do dilema da segurança, John Herz, as relações internacionais obedecem a leis gerais que regem todas as relações dentro de grupos, como estados, gangues urbanas e mesmo relações entre animais, como demonstra no exemplo em que até dentro de um galinheiro se estabelece uma hierarquia de poder que faz com que o primeiro a se alimentar seja o mais poderoso, seguido pelos outros. ${ }^{12}$

Nesse contexto do dilema da segurança, a paz e a guerra são problemas fundamentais do paradoxo da autoridade, e, conforme observa Norberto Bobbio, desde o aumento do poder das armas, a paz internacional só pode ser alcançada por meio do império (força superior de uma potência sobre outras), implementado com base na extraterritorialidade, ou por meio da liga (acordo de estados entre si com o objetivo de dar vida a um poder comum), implementada por meio de um sistema multilateral fundado no respeito à palavra dada, no consentimento. ${ }^{13}$

Com o objetivo de compreender a relativização da soberania sob a perspectiva da evolução do tratamento do território pelo direito internacional, nas seções pertencentes tanto à Parte I quanto à Parte II, procuraremos observar, transversalmente, a implantação do direito internacional em três patamares, quais sejam: (i) direito internacional como função notarial, como redução a termo por escrito ou mediante consenso do que resultou do jogo de forças políticas; (ii) direito internacional como estrutura composta de princípios, regras e instituições de valores; (iii) direito internacional como agregador de

por mim? Em verdade, em verdade te digo: o galo não cantará sem que me renegues três vezes." \{13,38\}]). Há certa discussão sobre o assunto do canto do galo (gr.: a $\cdot \mathbf{l e} \cdot \mathbf{k t o} \cdot \boldsymbol{r o} \cdot \boldsymbol{f o} \cdot \boldsymbol{n i} \cdot \boldsymbol{a})$, devido à referência de Jesus a ele em conexão com a sua predição de que Pedro o negaria três vezes. Dizem que o canto do galo mencionado por Jesus na realidade se referia ao gallicinium romano, um sinal de hora, que se diz ter sido dado com cornetas pela guarda romana, postada nos baluartes da Torre de Antônia, em Jerusalém, e que era tocado no fim da terceira vigília da noite. Embora talvez não seja possível atribuir atualmente horários específicos a esses periódicos cantos do galo, basta saber que existiam, e que, antes de o galo cantar duas vezes, ocorrerem as três negações de Pedro. Disponível em :http://wol.jw.org/pt/wol/d/r5/lp-t/1200001003 Acesso em : 04 julho. 2019.

${ }^{12}$ HERZ, John. "Idealist Internationalism and the Security Dilemma". World Politics, v.2, n.2.p.157-180.

Political Realism and Political Idealism: A Study in Theories and Realities. Chicago: Chicago University Press, 1951.

${ }^{13}$ BOBBIO, Norberto. Thomas Hobbes. tradução Carlos Nelson Coutinho. $5^{\mathrm{a}}$ tiragem. Rio de Janeiro: Campus. 1991. p. 179. 
valores. Para tanto, buscamos responder às seguintes questões guias desta tese: (i) O que se entende por soberania estatal? (ii) Quais são suas características e limites? (iii) Qual é o processo que permitiu a relativização da soberania estatal no mundo contemporâneo?

Na parte I Doutrinadores do Estado e da Soberania, com base em estudo histórico e analítico, averiguaremos a formação da ordem jurídica estatal, euclidiana, tendo como pano de fundo a crise de autoridade experimentada com a desintegração da Respublica Christiana. Para tanto, como guia desse período longo e complexo da história do direito internacional, nos apoiaremos na interpretação do que se entende por ordem jurídica euclidiana, de acordo com Mireille Delmas-Marty, e no estudo doutrinário de quatro obras clássicas da filosofia política e do direito internacional. Desse modo, buscaremos destacar alguns homens públicos que diagnosticaram o problema do paradoxo da autoridade e que anteciparam soluções exemplares, de forma a se tornarem narrativas com valores universais.

$\mathrm{Na}$ parte I, nos apoiaremos naquilo que julgamos ser um método, em que Guilherme Assis de Almeida interpreta a gênese do valor com base na ideia arendtiana de juízo reflexivo. ${ }^{14}$ Como ensina Celso Lafer com respeito à diferença entre juízo e juízo reflexivo, a determinação do valor por meio da validade exemplar é uma consequência do pensar, uma faculdade em que o particular é dado e se precisa encontrar o geral:

o juízo tem como objeto um particular que já foi (por exemplo, uma obra, um evento etc) e [...] , não se confunde com o pensar, pois é uma faculdade pela qual se juntam o geral - sempre uma construção mental - e o particular - sempre dado pela experiência espacialmente localizada. ${ }^{15}$

A escolha dos doutrinadores do estado e da soberania, como veremos, tem como propósito retratar teorias que se tornaram universalmente aceitas, sob o julgamento do senso comum da pluralidade de homens; exemplos históricos de relações intersubjetivas na espacialidade da vida pública,sob o pano de fundo da dissolução da Respublica Christiana e da crise de autoridade, o que se desdobrou no tratamento do território no direito internacional, mais contemporaneamente entendido como produto da história e da cultura humana. ${ }^{16}$ Das lições de Emanuel Kant e sua Crítica do Juízo e Hannah Arendt e sua Vida

${ }^{14}$ ALMEIDA, Guilherme Assis de. A Proteção da Pessoa Humana no Direito Internacional: Conflitos Armados, Refugiados e Discriminação Racial. São Paulo: Editora CLA Cultural, 2018.

15 LAFER, Celso. Hannah Arendt: Pensamento, Persuasão e Poder. Rio de Janeiro: Paz e Terra, 1979. (Coleção O Mundo, hoje, v.35). p. 125/6.

${ }^{16}$ CASELLA, Paulo Borba. Direito Internacional dos Espaços. São Paulo: Atlas, 2009. p. xv/i. 
do Espírito, Celso Lafer indica que a "intersubjetividade é o campo por excelência da Política e do Direito", o que põe em destaque a importância do espaço público com o mundo intersubjetivo das aparências que se comunicam por meio da persuasão, a qual "o discurso requer, por dar-se no plural, a concordância potencial dos Outros da qual depende o agir conjunto." ${ }^{17}$ De acordo com Norberto Bobbio, o soberano inova a ordem jurídica e a forma como o poder é formado e exercido, ao estabelecer duas espécies de relações intersubjetivas: (i) com os outros soberanos, (ii) com os súditos. ${ }^{18}$ Como fenômeno político e jurídico e, portanto, intersubjetivo, o estado soberano tem a capacidade de monopolizar a autoridade, em dado espaço público, na relação do soberano com seus súditos. Esse monopólio da autoridade pode ser entendido como uma forma de concentração do poder, enquanto, nas relações intersubjetivas com outros soberanos, a soberania pode ser entendida como uma forma de divisão de poder. ${ }^{19}$

Na seção 1.1., discutiremos o autor Nicolau Maquiavel. Trata-se de estudo que busca compreender o pensamento e a obra de Maquiavel como parte integrante de um juízo reflexivo, por meio do qual seus exemplos universalizaram-se como valores. Nesse sentido, destacamos desse estudo a consagração do estado territorial, uma vez que sem o estado, o direito internacional não atingiria a universalidade da ação, o alerta dado por Maquiavel acerca das revoluções e da razão de estado, bem como a localização do autor na filosofia política.

Na seção 1.2., discutiremos o autor Jean Bodin. Trata-se de estudo históricoanalítico que busca compreender o pensamento e a obra de Bodin como parte integrante de um juízo reflexivo, por meio do qual a consagração do conceito de soberania se universalizou. Estudaremos a natureza real da soberania por ser um dos dados que caracterizam o estado, mormente sobre a especificidade do título jurídico do soberano sobre o território. Nesta seção, abordaremos a exceção à regra do direito internacional, qual seja a extraterritorialidade por meio do instituto da imunidade do estado, bem como debate acerca das características absolutistas.

$\mathrm{Na}$ seção 1.3., discutiremos Hugo Grócio. Trata-se de estudo em que nos reportaremos ao grande mito fundador do direito internacional, a Paz de Münster e Osnabrück e os tratados de Westphalia de 1648. Ao estudar Hugo Grócio, temos como

${ }^{17}$ CASELLA, Paulo Borba. Direito Internacional dos Espaços. São Paulo: Atlas, 2009. p. 124.

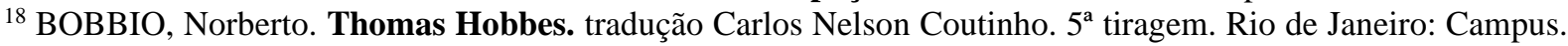
1991. p. 121.

${ }^{19}$ CASELLA, Paulo Borba. Direito Internacional dos Espaços. São Paulo: Atlas, 2009. 
objetivo discriminar seus juízos reflexivos com respeito ao exemplo do estudo das presas marítimas cujo debate se universaliza em torno da liberdade dos mares no contexto das grandes navegações e ocupações imperiais e dos espaços internacionais, domínios sem jurisdição estatal, em contraposição à territorialidade, de um lado, e, de outro, sua magna obra O Direito da Guerra e da Paz, em que se reporta ao jurista a constituição de uma sociedade internacional lastreada no direito natural, no consenso como vontade e expressão da justiça pelo que foi precipuamente escrito, na coordenação, na reciprocidade de direitos, na não discriminação, enfim, na igualdade jurídica dos estados com a exclusão do poder religioso.

Na seção 1.4., discutiremos Thomas Hobbes. Trata-se de estudo histórico analítico em que buscamos identificar o exemplo estudado por Hobbes com respeito ao contexto da guerra civil decorrente da problemática da unidade de poder. Nesse sentido, o Leviatã é a personificação do estado nacional em teoria e antecipou os eventos históricos das Revoluções Puritana, Gloriosa, Francesa e Americana. Tendo como base o ato de escolha dos indivíduos, a teoria hobbesiana do contrato social contribuiu para universalizar a ideia de indivíduo, uma das mais importantes manifestações de mudança de patamar na flexibilização da soberania nos séculos vindouros. O estado nacional, homem artificial, se, de um lado, se expandiu pelo mundo sob a forma de império da lei positiva, não conseguiu pôr fim ao estado de natureza nas relações interestatais.

$\mathrm{Na}$ parte II da pesquisa sobre a relativização da soberania, discutiremos as mudanças estruturais do direito internacional segundo análise pioneira de Wolfgang Friedmann, com base na mudança vertical no direito internacional, sob a forma da institucionalização da cooperação internacional. Dessa perspectiva, analisaremos a soberania por meio da relação entre o estado e o espaço no contexto pós-moderno, emergido dos escombros da Primeira Guerra Mundial, uma vez que podemos identificar o início de um processo de internacionalização do domínio reservado, por meio da quarta marca da soberania, identificada por Jean Bodin como "a última alçada, que é e sempre foi um dos principais direitos da soberania. ${ }^{20}$ Logo, o foco de nossa análise tem como base o desenvolvimento das teorias de competências e da soberania territorial, bem como a formação de duas 'camadas' de referência para o direito internacional decorrentes dessa relação entre estado e espaço. Nesse contexto de internacionalização da 'última alçada', 
analisaremos o conflito de jurisdições nacionais de forma particular pelo caso Lótus, e, de forma geral, pelo artigo $15, \S 8$ do Pacto da Sociedade das Nações, tendo como ponto de partida o exame de uma única fonte de direito: o Tratado de Paz de Versalhes de 1919 e seu anexo complementar, o Pacto da Sociedade das Nações. 


\section{EPÍlOGO: A SOBERANIA NO DIREITO INTERNACIONAL PÓS- MODERNO.}

Nossa pesquisa trilhou os caminhos sugeridos por Mireille Delmas-Marty com sua tese do pluralismo ordenado no que concerne (i) à formação da ordem jurídica euclidiana e por Paulo Borba Casella em sua proposta de direito internacinal do espaço com respeito à relação estado-espaço para a análise da soberania no contexto do direito internacional pósmoderno.

O primeiro diz respeito às condições históricas e estruturantes da ordem jurídica estatal de desintegração da Respublica Christiana, as quais implicam a formação e a operacionalização da hierarquia de um poder soberano sincronizado entre os que governam e os que são governados em um território delimitado por fronteiras.

Para as considerações do segundo, substituímos a noção vaga de espaço, por aquela acordada até o presente, segundo a qual o espaço representa "o movimento relativo a um corpo de referência praticamente rígido." ${ }^{1}$ A soberania com base na relação entre estado e espaço decorre da dinâmica resultante da sinergia de ordens jurídicas euclidianas envoltas em uma ordem internacional no contexto pós-moderno em que há operacionalização da jurisdição em vários níveis e de diversas formas de interação. Essas ordens legais buscam a estabilização, a afirmação e a continuidade do estado, em um mundo que envolve as unidades soberanas por meio da formação de um sistema normativo e institucional concorrente com a competência estatal, tida como um princípio decisivo do vínculo entre níveis de organização [nacional, regional e mundial] e processos de interação normativos [unificação, harmonia e coordenação]. ${ }^{2}$

Esse processo de expansão normativa se insere, muitas vezes, de forma concorrente à ação dos estados no plano internacional, o que, no contexto pós-moderno, como aponta Cláudia Perrone-Moisés, o direito internacional passa a ser orquestrado com base na fricção de duas 'camadas' estruturantes, regidas pela doutrina da soberania, de um lado, e, de outro, pela doutrina das fontes internacionais que habilitam e legitimam as ações das

1 EINSTEIN, Albert. Relativity: The Special and General Theory. Trad. Robert W. Lawson. 3. ed. University of Sheffield. 1920. p. 7. "In the first place, we entirely shun the vague word 'space', of which, we must honestly acknowledge, we cannot form the slightest conception, and we replace it by 'motion relative to a practically rigid body of reference,"'

2 DELMAS-MARTY, Mireille. Un Pluralisme Ordonné. In: Études Juridiques Comparatives et Internationalisation du Droit. Paris, 2006. Disponível em:https://www.college-de-france.fr/media/mireilledelmas-marty/UPL12910_r_sum_cours0405.pdf Data do acesso: 04 de julho de 2019. 
entidades soberanas internacionalmente. Essas fricções, por sua vez, representam perspectivas diferentes da interação jurídica em diversos níveis de organização mundial, à medida que o direito soberano de decidir em última alçada se relativiza conforme (i) a matéria debatida ou(ii) o impacto que as ações estatais provocam nos valores da comunidade de estados.

A autonomização institucional, legislativa e judiciária de 'espaços normativos,' destacados dos estados, contudo, não se opera de modo linear, na medida em que o fenômeno do desdobramento funcional se apresenta como uma dinâmica majoritária no processo nomotético e de sua operacionalização em diversos níveis e em diversas formas de interação, pois os principais agentes de criação e de operacionalização desses espaços normativos ainda são os estados soberanos, simultaneamente, autores, destinatários e representantes principais das normas de direito internacional. ${ }^{3} \mathrm{Na}$ prática, a relação pósmoderna entre estado-espaço configura-se, metaforicamente, como um movimento relativo da dispusta de cabo de guerra entre conjuntos normativos, em que estados soberanos e organizações internacionais concorrem pela delimitação ou pela isenção da competência estatal. Dessa disputa pela delimitação do domínio reservado, o imediatismo normativo entre soberania e direito internacional passa a ser mais sincronizado, na medida em que, para usarmos uma expressão de Louis Le Fur, as 'terras de ninguém' jurisdicionais são diminuídas em extensão e alcance. ${ }^{4}$

A renovação que sugerimos para o valor soberano diz respeito à formulação de um pensamento especulativo sobre a relação entre estado-espaço, bem como o fenômeno do imediatismo normativo, uma vez que ele expressa a autoridade do direito internacional que tem capacidade de vincular as interações de estados em uma estrutura de relações políticas em que nenhum sujeito de direito internacional detenha o monopólio legislativo e político, por isso, uma sociedade anárquica.Para tanto, faremos a avaliação da soberania com base nas mudanças estruturais do direito internacional por meio do uso da metáfora da matéria, baseada na ideia do átomo.

Argumentamos quea soberania, como um 'conceito esponja,'para tomarmos de empréstimo uma metáfora de Jens Bartelson, seja um dos lastros essenciais com o intuito

\footnotetext{
${ }^{3}$ NGUYEN QUOC, Dinh; PELLET, Alain; DAILLIER, Patrick. Direito Internacional Público. Tradução Vítor Marques Coelho. $2^{a}$ ed., Lisboa: Fundação Calouste Gulbenkian. 2003.

${ }^{4}$ LE FUR, Louis. Reconnaissance, Détermination et Signification en Droit international du Domaine Laissé par ce dernier à la Compétence Exclusive de l'État. Huitieme Commission. Travaux Préparatoires de la Session de Cambridge. In: Annuaire de 1’Institut de Droit International. 1931.
} 
de favorecer a formação de uma ordem jurídica pluralista harmônica e alternativa à fragmetação e à unificação normativas, com vistas à estabilização e à hierarquização das ordens jurídicas mediante a repartição do poder mundial, cuja partilha se volatiliza em razão do estado de natureza exasperado pela dispersão do valor referente à propriedade em uma mundialização anárquica e da projeção extraterritorial de normas de um império tendente à hegemonia.

Como argumenta Eelco Nicolas van Kleffens, a soberania não é um fantasma que pode ser exorcizado, quando quisermos, sob pena de se abandonar uma realidade que se impõe no plano dos fatos, pois, se, de um lado, se trata de um valor histórico, político e jurídico desenvolvido por antigas e longevas práticas estatais, responsável pela adesão maciça de corações e mentes individuais em torno das ideias de pátria e de nação; de outro, trata-se de um princípio diretor indispensável para a formação da ordem jurídica internacional, não obstante se apresente como um valor contingente, incerto e, frequentemente, de difícil definição e determinação em conflitos de competência, em oposição à precisão das regras do direito. ${ }^{5}$

Como expressão de um pensamento especulativo, a analogia da soberania como um feixe de luz tem como suporte a intuição de "semelhanças no dessemelhante," na lição de Celso Lafer, uma vez que essa metáfora busca iluminar o que, por muito tempo, não pôde ser visto no direito e nas relações internacionais: a cooperação internacional e a dimensão humana do território.Como uma manifestação jurídica relevante do imediatismo normativo e, por conseguinte, para a relativização da soberania estatal absoluta, sob a forma de um abrangente sistema de proteção internacional de direitos humanos, a internacionalização dos direitos fundamentais, originada de um processo lento, violento e permeado de contradições, expandiu-se para além das fronteiras dos países ocidentais, englobando todo o mundo de forma a aprofundar a relação do ser humano com o direito internacional. Nesse contexto, a análise da evolução da dimensão humana do território encontra terreno fértil para a demonstração de nossa tese acerca da soberania ser imaginada como um feixe de luz em contexto do direito internacional pós-moderno. ${ }^{6}$

Sugerimos, para tanto, uma renovação da tradição do conhecimento sobre a natureza e a função da soberania como um valor relevante para a configuração do estado e

\footnotetext{
${ }^{5}$ KLEFFENS, Eelco Nicolass van, Sovereignty in Internacional Law: Five Lectures. V.082. In: Collected Courses of the Hague Academy of International Law. p.128.

${ }^{6}$ LAFER, Celso. Hannah Arendt: Pensamento, Persuasão e Poder. Rio de Janeiro: Paz e Terra, 1979. (Coleção O Mundo, hoje, v.35). p. 88/9.
} 
do direito internacional. Com a publicação da 'nova teoria' do território-competência no Archiv des Öffentliches Rechts, v. XX, elaborada por Ernst Radnitzky, o tratamento legal relativo ao território sofre relevante inflexão e, com ele, também a soberania, cujo entendimento se abre para um comportamento instrumental em que ela passa a ser concebida como um feixe de competência. ${ }^{7}$

Além do embasamento relativo à tradicional concepção da soberania como um feixe de competências derivada da nova teoria do território-competência, buscamos suporte no esforço teórico de Van Kleffens, que, ao observar a realidade dos fatos relativa à existência, estabilidade e durabilidade da soberania, teve o mérito compreendê-la, de modo pioneiro, como uma forma de energia radiante originada do poder mental e da vontade dos seres humanos. A teoria da soberania como uma expressão da energia humana direcionada para a formação de um governo com capacidade de garantir a lei como uma expressão consensual da vontade da comunidade é apresentada nas palavras do próprio jurista, segundo o raciocínio que segue:

Seres humanos são repositórios de poder mental, vontade. O que é poder? É energia, que seja qualquer coisa sob a influência de uma causa de alguma forma apropriada, de acordo com a definição geralmente aceita. Essa energia tem capacidade de deflagrar certa força. Enquanto a energia não é lançada, nenhuma força é liberada, a energia é potencial. A vontade é energia potencial. O que é necessário para deixar essa energia se liberar? Como dissemos: uma causa apropriada, e essa causa apropriada é tanto uma reação a algo quanto uma ideia consciente que uma pessoa em questão formou em sua mente de um objeto que ela deseja alcançar. Esse resultado desejado é, sem dúvidas, causado por uma atração de algo desejado, o que corresponde a um empenho, um 'appetitus' da pessoa atraída. E uma vez que existe uma infinitude de coisas desejadas, desde as coisas mais essenciais à vida até luxos e coisas espirituais, há uma infinitude de atrações e de aspirações. Agora, é evidente que, assim que duas ou mais pessoas são atraídas por uma e mesma coisa, há um conflito de forças, e esse conflito é regulado pela repressão da força maior em relação à menor, enquanto ela própria é desviada pela força menor de seu curso original, em maior ou menor grau. Isso não quer dizer que uma força física maior sempre ganhe. De modo algum. Estamos falando de forças da mente, que podem ter seu ímpeto aumentado quando sustentadas por força física, mas que podem comandar forças espirituais suficientemente poderosas para superarem a mera força bruta. A questão sobre qual energia ganha, aquela de $\mathrm{A}$ ou aquela de $\mathrm{B}$, depende de uma multitude de fatores, entre os quais considerações éticas ou estéticas ou suas contrapartes opostas são importantes. Todos esses seres humanos, portanto, irradiando

${ }^{7}$ Posteriormente, como nos indica Paulo Borba Casella em sua obra Direito Internacional dos Espaços, p. 689, essa nova teoria do território-competência seria republicada em artigos de 1906, 1907 e 1917. RADNITZKY. Ernst. Zur Lehre von der Treupflicht im Dientverhältnisse. Archiv für Öffentliches Recht, v. 20. n. 1.1906 ___ Die Rechtliche Natur des Staatsgebiets. Archiv für ÖffentlichesRecht, v. 20. n. 3. 1906; ___ Meeresfreiheit und Meeresgemeinshaft. Archiv für ÖffentlichesRecht, v. 22. n. 3/4. 1907. arts. cits., tb. publ. no Oesterreichische Zeitschrift für ÖffentlichesRecht, III, 1917. p. 452 ss. 
energia em uma multitude de direções, formam juntos o que chamamos de sociedade, grande ou pequena. ${ }^{8}$

Nações, povos e comunidades são formas institucionais que se reconhecem em relação a si e a outrem por intermédio de uma identidade narrativa capaz de direcionar as energias potenciais da vontade e do poder mental dos seres humanos para a formação da sociedade, e, como consequência, para a sincronização dessa múltipla vontade da comunidade na criação de uma instituição, um governo, que represente a vontade da comunidade e garanta que as decisões consensualmente aceitas como vinculantes se expressem na forma de lei para regular o comportamento do grupo. ${ }^{9}$ Em sentido semelhante ao argumento de Paul Ricouer, Yuval Harari explica como após a Revolução Cognitiva, com o surgimento de novas formas de pensamento e de comunicação entre 70 mil e 30 mil anos atrás, o Homo sapiens conseguiu ultrapassar o limite crítico de organização social, dando ensejo à implementação de uma autoridade ordenadora da sociedade, da seguinte forma:

O segredo foi provavelmente o surgimento da ficção. Um grande número de estranhos pode cooperar de maneira eficaz se acreditar nos mesmos mitos. Toda cooperação humana em grande escala - seja um Estado moderno, uma igreja medieval, uma antiga cidade ou uma tribo arcaica - se baseia em mitos partilhados que só existem na imaginação coletiva das pessoas. As igrejas se baseiam em mitos religiosos partilhados. [...] Os Estados se baseiam em mitos nacionais partilhados. [...] Sistemas judiciais se baseiam em mitos jurídicos partilhados. [...] Mas nenhuma dessas coisas existe fora das histórias que as pessoas inventam e contam umas às outras. Não há deuses no universo, nem nações, nem dinheiro, nem direitos humanos, nem leis, nem justiça fora da

${ }^{8}$ KLEFFENS, Eelco Nicolass van, Sovereignty in Internacional Law: Five Lectures. V.082. In: Collected Courses of the Hague Academy of International Law. p.127."Human beings are the repositories of mental power, willpower. What is this power? It is energy, energy being, according to the generally accepted definition, anything which, under the influence of a cause of some appropriate kind, is capable of setting off a certain force. As long as the energy is not released, setting off no force, the energy is potential. Will-power is potential energy. What is necessary to let this potential energy discharge itself? As we said: an appropriate cause, and this appropriate cause is either a reaction to something, or a conscious idea the person concerned has formed in his mind of an aim he wishes to attain. This desired result is undoubtedly caused by an attraction of the desired thing, corresponding to a striving, an "appetitus" in the person attracted. And since there is an infinity of desired things, from the things most essential in life to luxuries and things spiritual, there is an infinity of attractions and strivings. Now it stands to reason that as soon as two or more persons are attracted by one and the same thing, there is a conflict of forces, and this conflict is adjusted by the greater force repressing the lesser whilst being itself deflected by that lesser force to a greater or lesser extent from its original course. This is not to say that the greater physical force always wins. Not at all. We are speaking of forces of the mind, which may see their impetus increased when sustained by physical force, but which may command spiritual forces powerful enough to overcome mere brawn. The question as to whose energy wins, that of $\mathrm{A}$ or that of $\mathrm{B}$, depends on a multitude of factors, amongst which ethical and esthetical considerations or their opposite counterpart are important. All these human beings, thus radiating energy in a multitude of directions, form together what we call a society, large or small."

${ }^{9}$ RICOUER. Paul. Quem é o Sujeito de Direito? In: O Justo 1: A Justiça como Regra Moral e como Instituição. Tradução Ivone C. Benedetti. São Paulo: WMF Martins Fontes, 2008. p. 28. 
imaginação coletiva dos seres humanos. [...] Tudo se resumia a contar histórias e convencer as pessoas a acreditarem nelas. ${ }^{10}$

Independentemente da natureza da formação da sociedade, com a fundação de cidades, reinos, países, estados e impérios, surge uma necessidade real de governar e de sentir-se governado não apenas com base na posse de fato do poder, mas também por intermédio de uma justificação ética e jurídica sobre os vários modos com os quais se procurou dar, a quem detém o poder, uma razão para comandar, e a quem suporta o poder, uma razão para obedecer. Como vemos, a imagem de um estado que nasce do consenso recíproco de indivíduos singulares, originariamente livres e iguais, é uma pura construção do intelecto com lastro no modelo jusnaturalista.

Variadas como são as interações humanas de indivíduos, grupos e nações, por sua vez, como ensina Goffredo Telles Junior elas preenchem o espaço social por meio de campos, que são as áreas onde se manifestam as energias das pessoas. Corroboram esses apontamentos, as justificativas originadas de estudos da física moderna sobre o fenômeno eletromagnético, que apesar de serem de certa forma arbitrária, comenta Albert Einstein que o campo é o meio intermediário que torna possível operar as interações à distância desde partículas até instituições humanas no espaço. De forma análoga ao funcionamento do campo magnético, os efeitos da gravidade operam no sentido de produzir movimento de acordo com uma lei identificada da experiência, pela qual a intensidade da ação sobre um corpo diminui, conforme se aumentam as distâncias. ${ }^{11}$ Nesse sentido, destaca Telles que a pessoa e o campo constituem uma realidade indissociável, na medida em que os movimentos relativos entre as pessoas não são vazios, mas, sim, campos onde as interações humanas exercem influências umas sobre as outras dentro de um ou de múltiplos campos simultâneamente. Essa relação entre campo e pessoa humana, nas palavras do próprio jurista, é explicada da seguinte maneira:

O certo é que campos existem por toda a parte e em todos os tempos. E não só entre os corpos, mas dentro deles também, porque dentro dos corpos, existem imensos espaços, que parecem vazios, sem matéria nenhuma, mas que são autênticos campos. Os campos são tão verdadeiros e universais quanto a matéria. O vácuo ou vazio não existe. O vácuo não é vazio: é campo. Só matéria e campo enchem todo o espaço. [...] Ambos, em igual medida, são aspectos da matéria. São as duas formas fundamentais e primárias da matéria como tal. [...] Nesses campos, é que as pessoas e os grupos humanos agem uns sobre os outros. Neles,

${ }^{10}$ HARARI, Yuval. Sapiens - Uma Breve História da Humanidade. Tradução: Janaína Marcoantonio.26ed. Porto Alegre, RS:L\&PM, 2017. p. 35/8.

${ }^{11}$ EINSTEIN, Albert. Relativity: The Special and General Theory. Trad. Robert W. Lawson. 3.ed. University of Sheffield. 1920. p. 52. 
portanto, é que se dão as interações das pessoas e dos grupos. [...] A pessoa e sua interação constituem duas coisas que não se separam. Não existem pessoas sem interação. A interação das pessoas não é algo produzido de fora, algo de acrescentado, mas é parte integrante e natural de sua estrutura. A estrutura da pessoa é um reflexo de todas as suas interações. Nenhuma pessoa seria o que é se não fosse a ação que ela exerce sobre as outras pessoas, e a ação das outras pessoas sobre ela. ${ }^{12}$

A relação entre campo e pessoa humana equivale, em uma escala maior no nível de organização, a relação entre estado e espaço, ou melhor, entre as interações das competências estatais inerentes ao estado, uma vez que tomamos como pressuposto que os estados são instituições humanas e não diabólicas, no dizer de Van Klefflens, dirigidas por seres humanos, que têm objetivos e interesses, e estão sujeitas ao jogo das forças intersubjetivas da soberania tanto nas relações políticas domésticas entre governo e povo quanto nas relações exteriores entre governos e, mais, contemporaneamente, entre governos e organizações internacionais.

Diante da formação da ordem pós-euclidiana, em que as interações entre os assuntos domésticos e os temas de cooperação internacional se situam dentro de vários campos jurisdicionais ao mesmo tempo, da perspectiva de sua geneologia política, a característica contingente da soberania decorre menos das promessas e das falhas do iluminismo em torno dos valores de revolução e da emancipação humana pela história e mais, preferencialmente, pelo choque aleatório e sem intenção entre conceitos e forças básicas do conhecimento moderno. Como argumenta Bartelson, não devemos esperar que a soberania se mantivesse incólume em sua habilidade de organizar a realidade intersubjetiva das relações políticas domésticas e exteriores, diante da contingência dos movimentos diáleticos das forças do conhecimento "entre um a priori e um a posteriori, entre o empírico e o transcendente, entre o sujeito e o objeto, entre o universal e o particular, entre a dialética finalista e a historiografia presentista, entre o Homem e o Outro." 13

De uma concepção onipotente, senhorial, autárquica e patrimonial, a soberania como um feixe de competências passa a ser concebida funcionalmente, e como especifica Max Huber em suas observações ao relatório Le Fur sobre o significado de competência:

12 TELLES JUNIOR, Goffredo. Direito Quântico: ensaio sobre o fundamento da ordem jurídica.9. ed., São Paulo: Saraiva, 2014. p. 84; 272.

${ }^{13}$ BARTELSON, Jens. A Genealogy of Sovereignty. London: Cambridge University Press, (Cambridge Studies in international relations: 39), 1995. p. 246/7. "The modern notion of sovereignty [...] emerges as the unintended consequence of the clash between the core concepts and forces of modern knowledge, between the a priori and the a posteriori, between the empirical and the transcendental, between the subject and object, between the universal and the particular, between philosophy and history, between finalist dialectic and presentisthistoriography, between Man and his Other." 
"se pressupõe uma repartição do poder entre as partes de um todo." Dessa foma, a soberania como um feixe de competências contribui para a tomada de consciência da comunidade internacional acerca da existência de interesses comuns.Apesar de, no âmbito das relações internacionais, essa mudança de concepção não ser instantânea nem plena, uma vez que, de acordo com o próprio Huber, a competência se expressa como "o direito do Estado a uma esfera de ação independente, com relação aos outros Estados," o que, observamos, no contexto pós-euclidiano,não é a negação da independência dos estados, mas, sim, a afirmação da necessidade imperiosa da realidade interdependente na família de nações. ${ }^{14}$

Conforme obsevado pela análise do caso Vapor de Lótus pela Corte Permanente de Direito Internacional, das consequências aleatórias e não intencionais dos conflitos de campos jurisdicionais nos movimentos relativos de entidades soberanas no espaço para com a criação do sistema internacional regulado, parcialmente, pelo direito internacional, evidencia-se a tensão criadora do imediatismo normativo na busca do equilíbrio entre a existência de múltiplas soberanias e o direito internacional, como estrutura da unidade do direito comum. Ensina Telles que o enigma da relação entre o um e o múltiplo tem como pressuposto a continuidade e a permanência, pois "toda existência tem por condição a estrutura" cuja natureza é a estabilidade, que depende de uma disposição ordenada de forças que a compõem. Nesse sentido, o jurista destaca a característica relativa da estabilidade, uma vez que "a estabilidade da estrutura depende do equilíbrio de forças e da harmonia de movimentos dos elementos que a constituem. A inexistência de equilíbrio e de harmonia implica inexistência de estabilidade e, por conseguinte, inexistência de estrutura." Dessa relação interdependente entre estabilidade, estrutrura e existência, podemos definir ordem como a "disposição conveniente de seres, para a consecução de um fim comum," relacionando e fazendo dos múltiplos e diversos seres, "partes de um só todo, ou seja, partes de uma unidade," o que nos leva a poder definir ordem como "uma unidade feita do múltiplo." Dessa forma, evidencia-se que a ordem implica multiplicidade

${ }^{14}$ LE FUR, Louis. Reconnaissance, Détermination et Signification en Droit international du Domaine Laissé par ce dernier à la Compétence Exclusive de l'État. Huitieme Commission. Travaux Préparatoires de la Session de Cambridge. In: Annuaire de 1'Institut de Droit International. 1931. p. 77. " « Compétence » présuppose une répartition de pouvoirs sur des parties d'un ensemble. Aussi longtemps que la soi-disant communauté internationale n'est pas organisée, c 'est-à-dire avant la S. D. N., il n 'y a pas de « compétences des Etats, au sens propre du mot, mais seulement des « droits » d'Etats à l'égard d'autres Etats. " 
e unidade, calcada na "dominação da unidade sobre o múltiplo," por intermédio da interação dos campos jurisdicionais relativos à repartição do poder mundial. ${ }^{15}$

Como decorrência da validade e da efetividade com que a soberania estatal e a territorialidade norteiam a formulação e a operacionalização das múltiplas instituições e normas internacionais, a ordem internacional, como unidade, permanece largamente territorializada e interestatal,sob a forma da adição de sistemas internos, dispostos lado a lado, tal qual o mapa político, em que nele se interagem os conjuntos normativos configurados em torno de princípios, normas e instituições, em um mundo, misteriosamente, concebido quadrimensionalmente, desde os trabalhos matemáticos de Hermann Minkowski, apresentados em sua famosa palestra "Espaço e Tempo" em 1908 na $80^{\mathrm{a}}$ Assembleia Alemã de Cientistas e Médicos.Sobre essa inovação para o conhecimento humano relativa ao espaço-tempo contínuo, cuja imagem se encontra no anexo sob a denominação de K, explica Einstein, tal como segue:

\begin{abstract}
Não estarmos acostumados a considerar o mundo no sentido de um continuumquadrimensional é devido ao fato de que, na física, antes do advento da teoria da relatividade, o tempo desempenha uma função diferente e mais independente, quando comparada com as coordenadas do espaço. É por essa razão que nos habituamos a tratar o tempo como um continuumindependente. De fato, de acordo com a mecânica clássica, tempo é absoluto, i.e., ele é independente da posição e da condição do movimento de um sistema de coordenadas. [...] A consideração de um 'mundo' de modo quadrimensional é natural na teoria da relatividade, uma vez que, de acordo com essa teoria, o tempo é roubado de sua independência. [...] Mas a descoberta de Minkowski, que foi importante para o desenvolvimento formal da teoria da relatividade, não está aqui. Ela deve ser encontrada no fato de seu reconhecimento de que o quadrimensional espaço-tempo continuum da teoria da relatividade, em suas mais essenciais propriedades formais, demonstra uma relação acentuada com o espaço geométrico tridimensional continuum Euclidiano. ${ }^{16}$
\end{abstract}

15 TELLES JUNIOR, Goffredo. Direito Quântico: ensaio sobre o fundamento da ordem jurídica.9. ed., São Paulo: Saraiva, 2014. p. 189/95. Sobre estrutura, exemplifica o jurista, nos seguintes termos: "O átomo é uma estrutura, uma armação estável, dentro do qual se agita uma constelação de movimentadas micropartículas. Um grão de areia, uma estrela, um vegetal, um homem são estruturas estáveis dentro das quais se movem os mais diversos componentes mutantes."

${ }^{16}$ EINSTEIN, Albert. Relativity: The Special and General Theory. Trad. Robert W. Lawson. 3. ed. University of Sheffield. 1920. p. 46/47. "That we have not been accustomed to regard the world in this sense as a fourdimensional continuum is due to the fact that in physics, before the advent of the theory of relativity, time played a different and more independent rôle, as compared with the space co-ordinates. It is for this reason that we have been in the habit of treating time as independent continuum. As a matter of fact, according to classical mechanics, time is absolute, i.e., it is independent of the position and the condition of motion of the system of co-ordinates. [...] The four-dimensional mode of consideration of the 'world' is natural on the theory of relativity, since according to this theory of time is robbed of its independence. [...] But the discovery of Minkowski, which was of importance for the formal development of the theory of relativity, does not lie here. It is to be found rather in the fact of his recognition that the four-dimensional space-time continuum of the theory of relativity, in it most essential formal properties, shows a pronounced relationship to the three-dimensional continuum of Euclidean geometrical space." 
A interação dos campos no mundo quadrimensional, configurado pelo espaçotempo continuum, é nossa contribuição para um novo entendimento da configuração da ordem jurídica internacional no contexto pós-euclidiano, uma vez queo exercício das competências estatais tanto em âmbito doméstico quanto internacional é realizado por meio da correlação do tempo e do espaço.

Como aponta Paulo Borba Casella, para que o direito não se aliene da realidade como mecanismo regulador das interações entre os sujeitos de direito internacional, não mais estritamente estatal, seus fundamentos devem ser identificados em seu tempo (histórico) e em sua dimensão (cultural). ${ }^{17}$ Ademais, o jurista explica o processo pelo qual o direito opera em consonância com o espaço-tempo, em razão das necessidades de delimitação espacial e da ação estatal que se impõem na interação entre as múltiplas soberanias, tal como segue:

os espaços físicos são submetidos a regimes legais, construídos a partir de
categorias fixadas no tempo, como modelos de atuação humana, onde se
combinam dados históricos, culturais, políticos como legais - não podem ser
capturados em abstrato, nem fora do tempo, embora digam respeito ao espaço.
Tempo e lugar, como facetas de fenômenos correlatos. ${ }^{18}$

O direito internacional funciona como uma força importante para a delimitação dos apetites dos soberanos por território e recursos, no mundo, crescentemente, percebido como comum, interdependente e único. Como um fenômeno mais próximo da realidade das interações entre estados, a interdependência tem sido base das mudanças estruturais do direito internacional, dado que, de uma secular interação basicamente horizontal na coordenação de regras de mútua abstenção, protetivas das entidades juridicamente iguais no sistema internacional, observamos a verticalização dos campos jurisdicionais por meio dos conflitos de competências que se apresentam na medida em que (i) estados passam a interagir entre si em temas carentes de cooperação positiva e (ii) as mudanças de níveis de organização jurídica resultantes da própria noção de internacionalização do direito estimulam a organização de regimes legais internacionais responsáveis por articular os interesses comuns dos estados por meio da criação de organizações internacionais que tendem para a permanência.

${ }^{17}$ CASELLA, Paulo Borba. Fundamentos do Direito Internacional Pós-Moderno. SP: Quartier Latin, 2008. p. 63.

${ }^{18}$ CASELLA, Paulo Borba. Direito Internacional dos Espaços. São Paulo: Atlas, 2009. p. xiv/xv. 
Desde o início da pós-modernidade com a institucionalização das organizações internacionais com alcance político universal, esse processo passou a influenciar mais diretamente o movimento relativo das ordens jurídicas euclidianas por meio do fenômeno decorrente da internacionalização da quarta marca da soberania, a qual Jean Bodin define como "a última alçada, que é e sempre foi um dos principais direitos da soberania." ${ }^{19} \mathrm{O}$ imediatismo normativo, como resultado da relação direta e inerente entre soberania e direito internacional, tem sido mais e mais relevante na limitação do domínio reservado dos estados. O processo de vinculação imediata entre o feixe de competências soberanas e o direitoprocura solucionar aporia longeva e renitente nas relações jurídicas e políticas entre nações, ao buscar a afirmação do direito internacional como uma autoridade legítima existente no sistema internacional anárquico, sem uma autoridade superiora. Trata-se da possibilidade de limitar uma soberania baseada na vontade absoluta, e, portanto, sem limites, por meio da fixação de regras e de princípios que delimitem o domínio reservado dos estados. Nesse sentido, a dominação da unidade sobre o múltiplo, demanda uma subversão dos interesses e vontades soberanas, lastreados numa obstinada concepção de soberania absoluta, cuja lógica de dominação opera no sentido de se exercitar as competências estatais sem limites externos nem responsabilidades coletivas, sob a forma de exercício extraterritorial de um poder pendente ao império ou na feitura das normas jurídicas internacionais que convém ao gosto do hegemônico.

$\mathrm{Na}$ falta, ou melhor, na dificuldade de se equilibrar a repartição do poder mundial crescentemente interdependente e comum para a preservação das comunidades políticas euclidianas, o que se observa é a formação de conjuntos normativos pouco estáveis e pouco duradouros. Com a criação da Organização das Nações Unidas, da perspectiva de um pluralismo ordenado, Delmas-Marty identifica uma mutação que afeta as próprias noções de ordem jurídica e de sistema de direito, em que se detecta uma oscilação de movimentos aparentemente contraditórios, - como integração e desintegração, expansão e recuo e sincronização e desincronização -, entre os polos da separação e da fusão dos conjuntos normativos.

Essa oscilação levou Delmas-Marty a usar a imagem da deformação das nuvens no céu em um dia com bastante vento, pois é gerada por forças que procuram aplicar a diretriz de 'implantação de compatibilidade de diferenças' tanto em escalas variadas de organização

${ }^{19}$ BODIN, Jean. Os Seis Livros da República: livro primeiro. Tradução Carlos Orsi Morel. 1.ed. São Paulo: Ícone, 2001. (Coleção Fundamentos do direito). p. 309. 
legal quanto pela existência de ritmos diversos (i) no interior das ordens jurídicas estatais e (ii) na interação dessas ordens na formação de 'espaços normativos' internacionais que as envolvam. Da proposta da jurista para superar os extremos da fusão de diversos conjuntos jurídicos, engendrada pela integração hegemônica das forças do mercado e das armas, e o da separação completa, surge a ideia do pluralismo ordenado que beneficie um projeto de ordem mundial jurídica múltipla, mas que não renuncie ao direito comum. Para superar essa dificuldade em torno da fragilidade das correlações relativas à atribuição dos campos jurisdicionais nacionais e funcionais, que repercutem para a estabilidade e a durabilidade dos conjuntos normativos, sugerimos fazer uso da soberania como um princípio diretor durável e estável no sistema internacional, não obstante sua natureza contingente e incerta, para podermos ter um vislumbre de qual seria o aspecto do "país de nuvens ordenadas," tal qual Delmas-Marty se pergunta.

Em um contexto internacional em que se observa a agregação de instituições e de valores que emaranham a formação e a aplicação das normas, a soberania passa por um processo de delimitação para que o direito internacional possa existir e operar. Como identifica Casella, o direito pode ser uma técnica de adaptação e adequação social guiado pelas decisões políticas e com suporte nos valores que dão sentido à adoção e a aplicação da norma. Dessa forma, como uma roupagem dos valores que representa, o direito vige pelo conteúdo do qual reveste, expressando os valores surgidos das relações sociais autorizadas em nível nacional, regional e internacional. ${ }^{20}$

Diante da conjuntura majoritariamente expressa em termos da territorialidade dos estados, sob alcunha da soberania territorial em que 'tudo o que está no território pertence ao território,'o desenvolvimento do direito internacional representa mais um agente facilitador para a ação plena e exclusiva do estado territorial, sob a guarida do princípio da não intervenção em assuntos internos e, por extensão, da independência, do que um meio de expressão válido e efetivo dos valores comuns para o apuro dessas múltiplas entidades soberanas como partes de uma comunidade internacional, solidária e interdependente de estados povoados por uma massa de indivíduos.

O dilema entre soberania e direitos humanos em odesejo das vontades soberanas entre a realização do apuro dos valores comuns e a resistência manifestada pelo estado territorial pode ser constatado, na Era da Catástrofe, se nos atentarmos para a dinâmica do

${ }^{20}$ CASELLA, Paulo Borba. Fundamentos do Direito Internacional Pós-Moderno. SP: Quartier Latin, 2008. p. $167 / 8$. 
equilíbrio concernente ao desenvolvimento, à operacionalização e à afirmação de sistemas de referência influentes no movimento de criação de uma ordem jurídica mundialmediante o controle do domínio reservado dos estados. ${ }^{21}$

Destacamos a avaliação desse movimento relativo entre estado territorial e a condição humana do indivíduo no período seminal da época do direito internacional da Humanidade, segundo caracterização de Heinhard Steiger, uma vez que, do resultado desse precário equilíbrio entre sujeito e objeto de direitos, resulta uma das maiores expressões da relativização da soberania no direito internacional público, com base na configuração da dimensão humana do território fixada pela estruturação do sistema internacional de



Para tanto, a análise histórica das condições para um equilíbrio pluralista com respeito à emergência do indivíduo como um sujeito de direito, em geral, e dos refugiados, em particular, na Era da Catástrofe, apresenta-se como um estudo de caso para nossa metáfora da soberania com a matéria sob a forma de energia, como um feixe de luz. Avaliaremos o processo de ajustes, reajustes, regulação e controle do fenômeno da internacionalização da quarta marca da soberania.

Como ensina, pioneiramente, Le Fur sobre a natureza indivisível e relativa da soberania nos debates iniciais sobre a verticalização do direito internacional, o estado não é o único sujeito de direito internacional e é um grave erro pensar que sua soberania é absoluta, ilimitada e exclusiva, pois se trata de uma qualidade da autoridade suprema, a autoridade mais alta para decidir sobre um determinado ponto, e não uma autoridade total e ilimitada, o que se reflete na possibilidade de serem partilhadas as suas atribuições em uma comunidade mais vasta. ${ }^{23}$

Para explicar o movimento relativo que imaginamos operar a relação entre estados, simbolizada pelo comportamento dos discos rígidos $\mathrm{L}$ na superfície esférica $\mathrm{K}$ na figura em anexo, em um contexto pós-euclidiano hipercomplexo em termos de oscilação dos conjuntos normativos decorrentes da superposição dos campos jurisdicionais nos diversos níveis de organização, como parte de nosso pensamento especulativo, procuramos destacar a soberania como um princípio diretor para a formação de um pluralismo ordenado durável

${ }^{21}$ HOBSBAWN, Eric J. Era dos Extremos: o Breve Século XX: 1914-1991. Tradução Marcos Santarrita. São Paulo: Companhia das Letras, 1995.

22 CASELLA, Paulo Borba. Direito Internacional dos Espaços. São Paulo: Atlas, 2009.

${ }^{23}$ LE FUR, Louis. Reconnaissance, Détermination et Signification en Droit international du Domaine Laissé par ce dernier à la Compétence Exclusive de l'État. Huitieme Commission. Travaux Préparatoires de la Session de Cambridge. In: Annuaire de 1’Institut de Droit International. 1931. p. 88. 
e estável com base no direito comum sob a forma de energia - que, como veremos, a soberania será representada pelo ponto luminoso N. Para tanto, recorremo-nos ao auxílio de Einstein para a explicação da dinâmica interativa entre corpos euclidianos e não euclidianos em seus diversos planos, tal como depreendemos da explicação abaixo sobre a figura existente no anexo:

\begin{abstract}
Nós devemos tentar superar essa barreira na mente, e o leitor paciente verá que, de forma alguma, essa é uma tarefa difícil. Para esse propósito, daremos, em primeiro, lugar atenção mais uma vez à geometria bidimensional de superfícies esféricas. Ao juntar a figura, deixemos $\mathrm{K}$ ser a superfície esférica, tocada em $\mathrm{S}$ por um plano, E, o qual, para a facilidade da apresentação, é mostrado no desenho como uma superfície delimitada. Deixemos L ser o disco na superfície esférica. Agora, vamos imaginar que no ponto $\mathrm{N}$ da superfície esférica, diametralmente oposto ao $\mathrm{S}$, exista um ponto luminoso, projetando uma sombra L' do disco $\mathrm{L}$ sobre o plano E. Cada ponto na esfera tem sua sombra no plano. Se o disco na esfera $\mathrm{K}$ é movido, sua sombra $\mathrm{L}$ ' no plano $\mathrm{E}$ também se move. Quando o disco L está em S, ele quase coincide exatamente com sua sombra. Se ele se afasta na superfície esférica para cima de $\mathrm{S}$, a sombra do disco L' no plano também se afasta de $\mathrm{S}$ no plano exterior, tornando- se cada vez maior. Conforme o disco $\mathrm{L}$ se aproxima do ponto luminoso $\mathrm{N}$, a sombra desloca-se para o infinito, e se torna infinitamente grande. Agora, colocamos a questão sobre quais são as leis de disposição das sombras esféricas L' no plano E? Evidentemente, elas são exatamente as mesmas leis de disposição dos discos $\mathrm{L}$ na superfície esférica. Já que para cada figura original em K, há uma sombra correspondente em E. Se os dois discos em K se tocarem, suas sombras em E também tocam. A geometria da sombra no plano concorda com a geometria do disco na esfera. Se chamarmos as sombras dos discos de figuras rígidas, então a geometria esférica deve ser aplicada no plano E com respeito a essas figuras rígidas. Além disso, o plano é finito com respeito às sombras dos discos, uma vez que somente um número finito de sombras encontra espaço no plano. ${ }^{24}$
\end{abstract}

Como um apelo à faculdade de imaginação humana, Einstein demonstra a dinâmica em que a geometria não euclidiana agasalha a geometria euclidiana. De forma análoga,

\footnotetext{
${ }^{24}$ EINSTEIN, Albert. Geometry and Experience. An Expanded Form of an Address to the Prussian Acaddemy of Sciences in Berlim on January 27th, 1921. InSidelights on Relativity. Trad.G.B. Jeffery and W. Perrett. 3. ed. University of Sheffield. 1922. Anex. p. 26/7. "We must try to surmont this barrier in the mind, and the patient reader will see that is is by no means a particularly difficult task. For this purpose we will first give our attention once more to the geometry of two-dimensional spherical surfaces. In the adjoining figure let $\mathrm{K}$ be the spherical surface, touched at $\mathrm{S}$ by a plane, $\mathrm{E}$, which, for facility of presentation, is shown in the drawing as a bounded surface. Let $\mathrm{L}$ be a disc on the spherical surface. Now let us imagine that at the point $\mathrm{N}$ of the spherical surface, diametrically opposite to $\mathrm{S}$, there is a luminous point, throwing a shadow L' of the disc L upon the plane E. Every point on the sphere has its shadow on the plane. If the disc on the sphere $\mathrm{K}$ is moved, its shadow $\mathrm{L}^{\prime}$ on the plane also moves. When the disc $\mathrm{L}$ is at $\mathrm{S}$, it almost exactly coincides with its shadow. If it moves on the spherical surface away from $S$ on the plane outwards, growing bigger and bigger. As the disc $\mathrm{L}$ approaches the luminous point $\mathrm{N}$, the shadow moves off to infinity, and becomes infinitely great. Now we put the question, What are the laws of disposition of thedisc-shadows L' on the plane E? Evidently they are exactly the same as the laws of disposition of the discs L on the spherical surface. For each original figure on $\mathrm{K}$ there is a corresponding shadow figure on $\mathrm{E}$. If two discs on $\mathrm{K}$ are touching, their shadows on $\mathrm{E}$ also touch. The shadow-geometry on the plane agrees with the disc-geometry on the sphere. If we call the disc-shadows rigid figures, then spherical geometry holds good on the plane $\mathrm{E}$ with respect to these rigid figures. Moreover, the plane is finite with respect to the disc-shadows, since only a finite number of the shadows can find room on the plane."
} 
podemos admitir que, tal como Delmas-Marty identifica, a ordem jurídica euclidiana encontra-se agasalhada por uma concepção pós-euclidiana de ordem jurídica, em que um de seus marcos seja a cooperação internacional na forma de verticalização da estrutura do direito internacional, tal qual apontada pioneiramente por Wolfgang Friedmann. ${ }^{25}$

Ao fazermos uso, por metáfora e analogia, domovimento relativo de corpos praticamente rígidos imaginado por Einstein, para superar as contradições existentes entre a teoria da relatividade e a experiência fundada na prática e na existência concreta de corpos rígidos, como o traço de luz observado quando a luz se propaga, podemos vislumbrar o desenho do 'emaranhado do mundo' no campo jurídico, nos atentando à internacionalização do direito como movimento da energia potencial para o ato da liberação das forças geradas por causas apropriadas, mediante processos de implantação da ordem jurídica em diversos níveis, sem desprezar as figuras que contribuem para situarmonos diante das oscilações entre os polos da separação e da fusão dos conjuntos normativos, causados por forças contraditórias geradoras de movimentos dialéticos de expansão e recuo, sincronização e desincronização, integração e desintegração.

Para nosso estudo de caso, em que destacamos o ius gentium como um limite externo aos estados mediante a afirmação de sua autoridade como sistema normativo e institucional, agregador de valores decorrente do movimento relativo entre entidades jurídicamente iguais, vale lembrar a lição de Yoram Dinstein em sua pesquisa sobre a interação entre tratados e costumes, segundo a qualo jurista aponta para o fato de que "todo direito dos tratados se apoia sobre o princípio geral do pacta sunt servanda,"que, para nosso estudo de caso, se apresenta como fonte normativa responsável pela criação do Pacto das Nações e pela positivação do artigo $15, \S 8 .{ }^{26}$ Da perspectiva da filosofia sobre o preceito de que os pactos devem ser observados, Paul Ricoeur entende que se trata de uma regra de reconhecimento que transcende as promessas face-a-face das relações interpessoais e que abrange a todos que vivam em uma mesma jurisdição e, "em se tratando de direito internacional ou humanitário, a humanidade inteira." ${ }^{27}$ Desse modo, identificamos um processo em que o fundamento de validade e de existêncio do direito internacional se desenvolve no sentido de sedimentar um consenso baseado num valor, não obstante

\footnotetext{
${ }^{25}$ FRIEDMANN, Wolfgang. Mudança da Estrutura do Direito Internacional. Tradução A.S. Araújo. Rio de Janeiro: Livraria Freitas Bastos S.A., 1971.

${ }^{26}$ DINSTEIN, Yoram. Interaction Between Treaty and Customs In: Collected Courses of the Hague Academy of International Law, The Hague Academy of International Law, (Vol.322), 2007. p. 260.

${ }^{27}$ RICOEUR, Paul. O Justo 1: a justiça como regra moral e como instituição. Tradução Ivone C. Benedetti. SP: WMF Martins Fontes, 2008. p. 28.
} 
ficcional, oriundo da experiência das interações entre soberanos com base, naquilo que Hugo Grócio identificou como a sacralidade dos pactos.

Compreendido como uma técnica,o direito pode ser usado para identificar sistemas de referência que operam no direito internacional e que expressam os valores que dão sentido, efetividade e autorização à norma nos conjuntos normativos, por meio da avaliação da intensidade, do tamanho e da direção dessas sombras ( $\left.L^{\prime}\right)$ no plano vinculado (E), como vemos na figura 2 do anexo.Como uma sombra ( $\left.\mathrm{L}^{\prime}\right)$ que se delineia num plano vinculado (E) desde a projeção da energia deflagrada pela vontade suprema da comunidade (N) que autoriza a vigência da lei, podemos afirmar que, dessa especulação, as 'camadas' do direito referentes às lógicas de Nuremberg e de Lótus não se friccionam como placas tectônicas para a determinação do direito, mas, sim, operam nos polos referentes aos movimentos de separação, fundados na doutrina da soberania, e de unificação, calcado na doutrina das fontes jurídicas, da perspectiva do pluralismo ordenado.

A soberania territorial passa a ser posta à prova com a positivação do artigo $15, \S 8$ do Pacto da Sociedade das Nações sobre a delimitação da competência exclusiva do estado pelo direito internacional. Desde então, inicia-se mais permanentemente uma discusão em torno do processo de cerceamento da existência de 'terras de ninguém' jurisdicionais, decorrentes do movimento relativo entre sujeitos de direitos internacionais. Com suporte na explicação do movimento relativo de discos rígidos (L) na superfície esférica $K$, da figura 2, podemos imaginar como a interação entre ordens jurídicas euclidianas se comportam num mundo quadrimensional contínuo e sem fronteiras.

Para contemplarmos essa situação, deveras inusual, quase beirando à utopia da insanidade do conceito de um mundo sem fronteiras, o que contradiz a realidade do sistema internacional, configurada pelo cerne lógico do sistema westphaliano (denominado pela Paz de Westphalia de 1648, segundo o qual a soberania atua como um princípio guia das relações estatais, pois reflete o monopólio mantido pelos estados sobre seus territórios), recorremos-nos ao auxílio de Einstein para explicar relatividade dos campos de interação políticas e jurídicas dos estados em um mundo quadrimensional contínuo e não delimitado, por meio da comparação das leis de disposição do espaço entre a geometria euclidiana de um plano ou de cubos e a geometria não euclidiana de uma superfície esférica, tal como segue:

O que desejamos expressar, quando dizemos que nosso espaço é infnito? Nada mais do que podemos colocar qualquer número de corpos de igual tamanho lado a lado sem nunca preencher o espaço. Suponha que tenhamos uma grande quantidade de cubos de madeira todos do mesmo tamanho. De acordo com a 
geometria euclidiana, podemos colocá-los acima, ao lado, um atrás do outro, de modo a preencher uma parte do espaço de quaisquer dimensões; mas esta construção nunca teria fim; poderiamos adicionar mais e mais cubos sem jamais verificar que não existe mais espaço. É isso que desejamos expressar, quando dizemos que o espaço é infinito. Seria melhor dizer que o espaço é infinito em relação aos corpos praticamente rígidos, ao assumir que as leis de disposição desses corpos são dadas pela geometria euclidiana. Outro exemplo de um infinito continuumé o plano. [...] Assim, dizemos que o plano é um infinito continuum de duas dimensões, e o espaço um infinito continuum de três dimensões. O que aqui significa o número de dimensões, eu acho que eu posso assumir ser reconhecido. Agora, tomamos o exemplo de um continuumbidimensional que é finito, mas não delimitado. Imaginamos a superfície de um largo globo e uma quantidade de pequenos discos de papel, todos do mesmo tamanho. Colocamos um dos discos em qualquer lugar da superfície do globo. Se movermos o disco em qualquer lugar que queiramos na superfície do globo, não encontramos um limite ou fronteira em nenhum lugar da jornada. Logo, dizemos que a superfície esférica do globo é um continuumsem limites. Além disso, a superfície esférica é um finito continuum.Porque se aderirmos discos de papel no globo, de modo a nenhum disco sobrepôr-se, a superfície do globo finalmente se tornará tão cheia que não haverá espaço para outro disco. Isso simplesmente significa que a superfície esférica do globo é finita em relação aos discos de papel. Além disso, a superfície esférica é um continuum não Euclidiano de duas dimensões, o que significa dizer que, as leis de disposição para as figuras rígidas situadas nela não combinam com àquelas do plano Euclidiano. Isso pode ser visto da seguinte forma. [figura 1 no anexo]. ${ }^{28}$

\section{Compreendido como ordem, o sistema internacional decorre da soma de sistemas}

internos, dispostos lado a lado, tal qual o mapa político e a figura 1 no anexo, e nele se

${ }^{28}$ EINSTEIN, Albert. Geometry and Experience. An Expanded Form of an Address to the Prussian Acaddemy of Sciences in Berlim on January 27th, 1921. InSidelights on Relativity. Trad.G.B. Jeffery and W. Perrett. 3. ed. University of Sheffield. 1922. Anex. p. 26/7. "What do we wish to express when we say that our space is infinite? Nothing more than that we might lay any number whatever of bodies of equal sizes side by side without ever filling space. Suppose that we are provided with a great many wooden cubes all of the same size. In accordance with Euclidean geometry we can place them above, beside, and behind one another so as to fill a part of space of any dimensions; but this construction would never be finished; we could go on adding more and more cubes without ever finding that there was no more room. That is what we wish to express when we say that space is infinite. It would be better to say that space is infinite in relation to practically-rigid bodies, assuming that the laws of disposition for these bodies are given by Euclidean geometry. Another example of an infinite continuum is the plane. On a plane surface we may lay squares of cardboard so that each side of any square has the side of another square adjacent to it. The construction is never finished; we can always go on laying squares - if their laws of disposition correspond to those of plane figures of Euclidean geometry. The plane is therefore infinite in relation to the cardboard squares. Accordingly we say that the plane is an infinite continuum of two dimensions, and space an infinite continuum of three dimensions. What is here meant by the number of dimensions, I think I may assume to be known. Now we take an example of a two-dimensional continuum which is finite, but unbounded. We imagine the surface of a large globe and a quantity of small paper discs, all of the same size. We place one of the discs anywhere on the surface of the globe. If we move the disc about, anywhere we like, on the surface of the globe, we do not come upon a limit or boundary anywhere on the journey. Therefore we say that the spherical surface of the globe is an unbounded continuum. Moreover, the spherical surface is a finite continuum. For if we stick the paper discs on the globe, so that no disc overlaps another, the surface of the globe will finally become so full that there is no room for another disc. This simply means that the spherical surface of the globe is finite in relation to the paper discs. Further, the spherical surface is a non-Euclidean continuum of two dimensions, that is to say, the laws of disposition for the rigid figures lying in it do not agree with those of the Euclidean plane.This can be shown in the following way. Place a paper disc on the spherical surface, and around it in a circle place six more discs, each of which is to be surrounded in turn by six discs, and so on. If this construction is made on a plane surface, we have an uninterrupted disposition in which there are six discs touching every disc except those which lie on the outside." 
inscreve o conjunto de princípios, de normas e de instituições. Como decorrência da validade e da efetividade com que a soberania estatal e a territorialidade norteiam a formulação e a operacionalização das instituições e normas internacionais, o sistema internacional permanece largamente interestatal e territorializado, fundamentado no longevo e estável princípio "quidquid est in territorio, est etiam de territorio. "Como bem observa o geográfo John Agnew, a lógica westphaliana desenvolveu-se desde suas raízes europeias para abranger o mundo todo, e, por isso, não há espaço entre ou em volta desses sujeitos de direito em suas interações políticas e jurídicas. ${ }^{29}$ Corrobora essas argumentação da perspectiva da geografia política, comentário de Norberto Bobbio, segundo o qual como se sabe, nenhum Estado está só. O jurista lembra-nos que "todo Estado existe ao lado de outros. Estados numa sociedade de Estados." E complementa que, "como as cidades gregas, assim são os Estados contemporâneos." No que diz respeito ao modo como os Estados se relacionam, Bobbio é cristalino ao afirmar que "toda forma de convivência, mesmo aquela sem leis do estado de natureza, comporta limites à conduta de cada um dos conviventes." ${ }^{30}$

Diversamente da secular e obsoleta teoria que legitimava o direito do estado sobre o território com base no direito de propriedade e de domínio eminente (real) do soberano, com a' nova teoria do território-competência', uma nova concepção de soberania é aberta, no sentido de que o território passa a ser concebido como um lugar onde o estado exerce as competências não mais sobre coisas, mas, sim, como um atributo usado pelo direito internacional para delimitar a competência da soberania estatal sobre pessoas e atividades. ${ }^{31}$ Como nos relata Casella, como base doutrinária precedente e inovadora da tradição legal acerca do território, a teoria do território-competência penetraria o direito internacional por meio da escola austríaca, com a publicação da obra Allgemeine Staatslehre, em 1925, de Hans Kelsen, o qual observava, originalmente, que os territórios dos estados não são superfícies, mas volumes icônicos, cujas extremidades alcançam o centro da terra, sendo que, por fim, a elaboração doutrinária mais bem acabada somente seria realizada após o julgamento do caso Lótus, pela pena de Alfred Verdross, segundo o

${ }^{29}$ AGNEW, John. Globalization and Sovereingty.United Kingdom: Rowman \& Littlefield Publishing Group, 2009. p.79.

${ }^{30}$ BOBBIO, Norberto. Estado, governo, sociedade: por uma teoria geral da política. Tradução Marcos Aurélio Nogueira. RJ: Paz e Terra, 1987. p. 101 (Coleção Pensamento Crítico, v.69)

31 MELlo, Celso D. de Albuquerque. Curso de Direito Internacional Público. 14 ed. Rio de Janeiro: Renovar, 2002. p. 1073/5. 
qual denominou de soberania territorial o direito exclusivo de o estado exercer certos poderes sobre tudo o que estivesse dentro do território. ${ }^{32}$

$\mathrm{O}$ processo relativo à delimitação dos campos de interesse comum no sistema internacional não é linear e nem definitivo, uma vez que a estabilidade da unidade sob a forma de uma ordem jurídica pluralista e ordenada com base no direito comum depende do equilíbrio de forças e da harmonia de movimentos que delimitam os campos decisivos para a vinculação entre os processos de interação e os níveis de organização de um pluralismo ordenado, qual seja: a soberania sob a forma de feixe de competências.A "questão de saber, se certa matéria entra ou não no domínio exclusivo de um Estado é essencialmente uma questão relativa: ela depende do desenvolvimento das relações internacionais," conforme afirmou a Corte Permanente de Justiça Internacional em seu parecer consultivo $\mathrm{n}^{\circ} 4$ acerca dos Decretos de Nacionalidade Promulgados pela Tunísia e pelo Marrocos. ${ }^{33}$

De forma mais específica e doutrinária para a determinação da relatividade da delimitação do domínio reservado dos estados, quando existe um terreno não delimitado pelo direito internacional, mormente em conflitos de ordem política, em que a faceta política da soberania condiciona a efetividade da jurídica mediante o uso do monopólio legítimo da força, Max Huber, em observação ao relatório Le Fur, explica que a competência estatal pode ser exclusiva ou relativa. Por isso, a questão principal para saber se uma competência é exclusiva do estado reside em determinar se o domínio reservado é fundado em um princípio abstrato ou por regras concretas, ou pelos dois. A definição do campo jurisdicional do estado pode ser delimitada por meio do sopesamento entre esses critérios, os quais o jurista identifica alguns princípios abstratos, tais como os seguintes:

(i) independência do estado como única organização legítima para manuseio da força coercitiva legal, (ii) a ideia de uma comunidade de estados, (iii) o caráter essencialmente territorial do estado, com direito pleno e exclusivo de ação em seu território, (iv) a existência de territórios acessíveis à ação do estado, mas fora de seu território, (v) a característica acessória dos estados como união de pessoas distribuídas em diversos estados. ${ }^{34}$

${ }^{32}$ CASELLA, Paulo Borba. Direito Internacional dos Espaços. São Paulo: Atlas, 2009. p. 251.

${ }^{3}$ C.P.J.I. Décrets de Nationalité Promulgués en Tunisie et au Maroc. Avis Consultif. Série B., nº 4, p. 24..Disponível em: https://www.icj-cij.org/fr/cpji-serie-b Acessado em: 07/01/2020. "La question de savoir, si une certaine matière rentre ou ne rentre pas dans le domaine exclusive d'un État est une question essentiellement relative: elle dépend du développement des rapports internationaux."

${ }^{34}$ LE FUR, Louis. Reconnaissance, Détermination et Signification en Droit international du Domaine Laissé par ce dernier à la Compétence Exclusive de l'État. Huitieme Commission. Travaux Préparatoires de la Session de Cambridge. In: Annuaire de 1'Institut de Droit International. 1931. p. 84/5. "Les principes qui peuvent servir à déterminer, d'une manière abstraite, la compétence exclusive doivent être dégagés de la genèse du droit international contemporain. Ils sont :a) L'indépendance naturelle de 
Como ensina Casella, "não se pode entender a norma, reduzindo-a aos elementos aos quais ela se refere: direito é fenômeno real, empírico, se desenvolve histórica e culturalmente. Seu caráter complexo decorre da conjunção de conteúdos abstratos e suportes concretos." ${ }^{35}$ Em um quadro de paulatina inserção do ser humano enquanto objeto e sujeito da ordem jurídica internacional, a redefinição e a adequação do estado territorial, contudo, tem no direito internacional mais uma forma de preservação da soberania do que de perfazimento dos valores comunitários existentes pela crescente interdependência de ordens jurídicas estatais. Nesse sentido, os direitos humanos, tidos como valores comunitários, são percebidos como uma aporia ao desenvolvimento e à preservação da soberania estatal, uma vez que a relação entre estado e espaço se expressa pela precedência que a competência territorial tem sobre a competência pessoal dos estados. Nesse sentido, corrobora argumentação de Van Kleffens que, se, de um lado, caracteriza a soberania absoluta como uma delusão histórica, resultado da reação de reis ao império dos papas e dos imperadores, de outro, em seu epílogo, afirma que ela é um fato incontornável da realidade, tal como segue: "a noção de soberania em direito internacional mostrou no decorrer dos séculos a vitalidade, o vigor perene de uma realidade de primeira ordem." ${ }^{36}$

Diante desse contexto renitente na pós-modernidade de que os direitos fundamentais do homem são percebidos como um atraso e uma fonte de insegurança jurídica e de ameaça externa aos interesses nacionais, cabe a nós refletir sobre qual é o espaço dos direitos humanos para a realização de um equilíbrio pluralista em plena Era da Catástrofe.

Da especulação sobre a soberania ser percebida como uma forma de energia potencial mental das pessoas humanas, liberada mediante reação ou formação e desenvolvimento de uma ideia em que haja adesão social, leva-nos a afirmar que quanto mais essa delusão persistir entre a perspectiva dos que governam e daquelas dos povos que aspiram por liberdade, mais potencial soberano é disperdiçado, sob a forma de violações

l'Etat en tant qu'unique organisation sociale revêtue de force coercitive légale; b) L'idée de la communauté internationale (par opposition aux relations internationales des Etats de l'antiquité et des peuples primitifs) ; c) Le caractère essentiellement territorial de l'Etat et le monopole d'action étatique directe de ce dernier dans son territoire ;d) Le caractère accessoire de l'Etat comme union de personnes distribuées sur divers Etats;e) L'existence d'espaces accessibles à l'action des Etats, mais en dehors des territoires d'Etat.."

35 CASELLA, Paulo Borba. Fundamentos do Direito Internacional Pós-Moderno. SP: Quartier Latin, 2008. p. 168.

${ }^{36}$ KLEFFENS, Eelco Nicolass van, Sovereignty in Internacional Law: Five Lectures. V.082. In: Collected Courses of the Hague Academy of International Law. p.127. " The conclusion is, that the notion of sovereignty in international law has shown throughout the ages the vitality, the perennial vigour, of a reality of the first order." 
dos direitos humanos, o que pode ser imaginado como uma fonte de luz menos intensa e com menor alcance nos conjuntos normativos.

Além desse alerta, gostaríamos de fazer uma ressalva dessa analogia para com a teoria do pluralismo ordenado, que, em si, como Delmas-Marty expõe, é a arte da combinação de ritmos e de maneira justa da velocidade de cada sociedade, de cada conjunto normativo, seja nacional, seja internacional. O único senão, aparente, dessa analogia reside no fato de que se trata de um tipo ideal, no sentido de que, dada a natureza dual da luz [corpo e onda], a velocidade da luz apresenta-se como uma constante, seja qual for a velocidade do deslocamento da fonte luminosa. Os ajustes e desajustes que a jurista observa da corrida de velocidades entre os conjuntos normativos, ao privilegiar a cinética jurídica no estudo do pluralismo, podem, contudo, serem observados com base no princípio fundamental da relatividade do movimento, calcado na rigorosa constância da velocidade da luz, e, por extensão, para nossa analogia, na igualdade jurídica e soberana dos estados, sob a denominação do ponto luminoso $\mathrm{N}$ da figura $2 \mathrm{em}$ anexo. Entendemos que a simultaneidade como um dos critérios da ordem jurídica euclidiana será melhor compreendida com base na determinação de sistemas de referência que possibilitem a interação de sistemas jurídicos nacionais, calcados nas interações entre os campos jurisdicionais relativos à determinação das competências estatais. Dessa realidade matemática escancarada pelo postulado da teoria da relatividade, explica sinteticamente Telles:

Em 1924, Louis de Broglio declarava que os fenômenos de caráter ondulátorio evidente, como a luz, não eram os únicos a possuir propriedades corpusculares.[...] Corpo e onda - este é, em verdade, o surpreendente dualismo, que a Física Moderna descobriu em todas as micropartículas. [...] Somente onde as velocidades são imensas, os corpos se comportam como ondas, e as ondas se comportam como corpos. [...] Este é um fato realmente excepcional. Em regra, a velocidade de um corpo depende de muitos fatores, entre os quais a velocidade da fonte que originou o movimento do corpo em questão. [...] A velocidade da luz, porém, apresenta uma novidade única: ela não se altera com a velocidade de sua fonte. [...] Inferimos dessa experiência o princípio fundamental da relatividade do movimento. O tempo que um corpo leva para percorrer um certo espaço não depende somente de sua própria velocidade, mas depende, também, da velocidade com que se move o sistema de referência a que pertence o espaço a percorrer. Em outras palavras: a velocidade de um corpo se mede em razão da velocidade do sistema de referência com que esse corpo se relaciona.37

37 TELLES JUNIOR, Goffredo. Direito Quântico: ensaio sobre o fundamento da ordem jurídica.9. ed., São Paulo: Saraiva, 2014. p. 62/3;94/5. 
O processo de internacionalização da dignidade do ser humano tem sido uma referência relevante para a ordenação normativa e institucional do direito internacional, contudo, ainda resta um longo caminho para que se torne um valor prioritário nos cálculos geopolíticos dos estados. Entre os interesses nacionais fruto dos cálculos da razão de estado e aqueles fundamentados nos princípios elementares da dignidade humana, a balança tende a pender para o lado da razão, menos por causa da incompatibilidade da razão de estado e da ordenação teleologicamente humana do mundo, e mais por causa da relatividade dos destinatários das normas de direito internacional de acordo com as lógicas de operacionalização do direito, identificadas por Cláudia Perrone-Moisés, quais sejam a de Lótus e a de Nuremberg.

Enquanto a lógica de Lótus é a expressão do fato soberano, marcada pelo relativismo dos entes soberanos e pela descentralização da nomogênese internacional fundada em nível nacional, o que nos faz identificá-la mais perto ao polo próximo à(N) da figura 2 no anexo, em razão de sua qualidade fragmentária, dispersiva, autônoma, tendente à separação e ao isolamento; a de Nuremberg representa a ordenação do direito com vistas à proteção e à emancipação do ser humano por meios institucionais e normativos em um mundo de estados, o que nos permite identificá-la mais próximo ao polo $\mathrm{S}$ em contato com o plano vinculado E na figura 2 em anexo, em função de sua característica unificadora, integradora e harmonizadora das diversas ordens jurídicas euclidianas no mundo. ${ }^{38}$

O projeto de realização de uma ordem jurídica mundial apresenta uma contradição que se expressa, simultaneamente, pelos fenômenos (i) da verticalização do direito internacional por meio da ampliação e do preenchimento dos espaços normativos vinculados pelo direito, e (ii) da volatilização da ordem entre os polos referentes à unificação e à fragmentação, que é intensificada pelas ações oriundas dos interesses nacionais públicos e privados dos estados. Essas contradições em torno da integração, abrangência e aprofundamento dos espaços normativos em relação aos vínculos entre direito internacional e soberania, de um lado, e a falta do equilíbrio de forças que causa instabilidade e, por consequência, pouca durabilidade das estruturas do direito revelam uma tensão em torno da natureza do estado-nação e do domínio referente à validade e à efetividade do feixe de competência soberano quando do nível de organização [local, nacional, regional, mundial] e da forma de interação [unificação, harmonização e coordenação]. 
Em nosso estudo de caso sobre a emergência da pessoa humana como sujeito de direito internacional na vertente da proteção e garantias dos direitos de nacionais e estrangeiros, sob a forma de um abrangente sistema de proteção do direito internacional dos direitos humanos, os problemas dos refugiados e apátridas, durante a Era da Catástrofe, eram considerados problemas de ordem política, uma vez que, como vimos, as matérias de migração e nacionalidade diziam respeito à 'vida intíma' dos estados, e, portanto, não eram regulados pelo direito internacional. O processo de 'fechamento das portas' jurisdicionais se desenvolveu mais de forma reativa da comunidade internacional para com os crescentes problemas fronteiriços causados pelas expulsões e desnacionalizações em massa oriundas, sobretudo, dos regimes nazista e soviético, do que foi fruto de um ideal condizente com os direitos fundamentais das pessoas e da sagrada missão das nações civilizadas. Por se tratar de uma área carente de cooperação positiva, o problema relativo à emancipação da condição do indivíduo dentro do direito internacional tem se revelado fonte de controvérsias políticas, doutrinárias e jurisprudenciais, as quais se aplicam, sobretudo, a dois elementos vitais da estrutura do direito internacional, quais sejam: (i) o direito de nacionalidade que põe o indivíduo como objeto de reivindicações válidas dos estados no exercício de seus direitos e (ii) as responsabilidades dos países por danos causados a estrangeiros. $^{39}$

Não obstante a soberania apresente dualidade tendente ao monopólio tanto jurídico quanto político das competências territorial e pessoal dos estados, a tentação positivista da soberania absoluta, baseada na caricatura da lógica de Lótus segundo a qual tudo o que não é proibido é permitido, tem sido desestimulada, na ordem jurídica pós-euclidiana, à proporção que, no direito internacional, para tomarmos de empréstimo a metáfora do juiz Loder no caso Vapor de Lótus, se tem procurado 'fechar a porta' das vontades absolutas por meio da aplicação e do desenvolvimento das fontes do direito internacional, como costumes, tratados e princípios gerais, para limitar a liberdade de ação dos estados.

Antes da Sociedade das Nações como instituição vanguardista para a organização da comunidade internacional, relata-nos Huber que havia apenas direitos dos estados nas relações entre si; com a positivação do artigo $15, \S 8$ do Pacto $\mathrm{SdN}$, passa a existir a competência, como o campo jurisdicional em que o poder, existente no mundo quadrimensional do espaço-tempo continuumé repartido entre os estados, que, em nosso

${ }^{39}$ FRIEDMANN, Wolfgang. Mudança da Estrutura do Direito Internacional. Tradução A.S. Araújo. Rio de Janeiro: Livraria Freitas Bastos S.A., 1971. 
estudo, chamamos por analogia e metáfora de K na figura 2 em anexo. Da conciliação dos princípios acima elencados para a determinação do campo do domínio reservado, Huber sugere que a competência pode ser exclusiva ou relativa.

No exercício da soberania territorial dentro das fronteiras, a competência pode ser exclusiva, o que significa que nos assuntos domésticos dos estados, dentro das fronteiras, o exercício dela é, em princípio, ilimitado, pois há poucas regras do direito comum aplicáveis na regulação de temas, como nacionalidade, e, por extensão, naturalização e desnacionalização, e migração, por extensão, expulsão e deportação. No caso da competência exclusiva, ela tem como referência de ação a lógica de Lótus, segundo a qual, se o direito não 'fechar a porta' jurisdicional ao regular e aplicar normas com base no pacta sunt servanda, a teoria do direito fundamental dos estados prevalece sobre o direito comum. Nesse sentido, as sombras legais $\left(L^{\prime}\right)$ tendem à dispersão, à fraca intensidade e pouco delineamento no plano vinculado $(\mathrm{E})$, por esterem mais próximas do polo onde $(\mathrm{N})$ se situa na figura 2 no anexo.

A competência também pode ser relativa em situações (i) em que há sobreposição de campos jurisdicionais em áreas não sujeitas à jurisdição estatal exclusiva, como o alto mar, ou (ii) em que o campo jurisdicional que se extende para outros territórios, como o direito internacional privado e as leis sobre nacionalidade, quando relacionadas à responsabilidade dos países por danos causados a estrangeiros. Nesse caso em particular, como norma costumeira assegurada por acordo de cortesia internacional [comitas gentium] decorrente da potencialidade do exercício da competência pessoal do estado da pessoa estrangeira e, por conseguinte, da imputação de responsabilidade do estado que não a protegeu, o direito internacional admite que é obrigação de cada estado assegurar um mínimo de segurança ao estrangeiros que se encontrem em seu território. Nesse sentido, em razão da potencialidade da reação da soberania estrangeira, a cortesia internacional é uma das poucas normas aplicáveis dentro das fronteiras territoriais com respeito ao estrangeiro.

O movimento relativo entre ordens jurídicas euclidianas com respeito à cortesia internacional, que é fundada tanto numa ideia consciente de que os estados são sujeitos soberanos iguais, segundo a tradicional regra de Bártolo, de que entre iguais não há jurisdição, levando ao reconhecimento das imunidades de jurisdição e de execução dos chefes de estado e dos diplomatas, quanto numa possível reação política da competência pessoal sobre a forma de proteção diplomática ou mesmo intervenção e guerra, provocou o afastamento dessas ordens do ponto luminoso $(\mathrm{N})$ em direção à $(\mathrm{S})$, que representa o polo 
da fusão e da comunhão de interesses mútuos, em que as fontes projetadas no plano (E), sob forma de sombras (L') ganham em intensidade, delineamento e diminuem de tamanho, e, por extensão, de escopo, conforme observamos na figura 2 no anexo. ${ }^{40}$

Por meio da reflexão acerca das condições de um equilíbrio pluralista, como ajustes, reajustes, regulação, depois avaliação e controle do estudo de caso histórico referente à emergência do refugiado como sujeito de direito da Proteção Internacional da Pessoa Humana, ao contemplar as fases de definição do Estatuto do Refugiado, podemos observar a falta de linearidade da internacionalização dos direitos humanos. Conforme aponta Guilherme Assis de Almeida, a SdN ainda apresentava uma mentalidade jurídica apoiada na 'missão sagrada da civilização,' o que tornava o Pacto um documento ambivalente para com o tema dos direitos humanos. Dessa maneira, a instituição ajustou-se mais de forma reativa do que impelida pelos ideais sagrados da civilização, quando o problema das pessoas deslocadas dizia respeito à população europeia, e não às populações sob jugo imperialista e colonialista dos estados oriundos do velho mundo, com base nas formas jurídicas de protetorado e mandatos. ${ }^{41}$

Durante a Era da Catástrofe, ao lidar com a questão dos apátridas, refugiados e minorias, a comunidade internacional, em geral, e a SdN, por meio de seus órgãos, em particular, procuraram deslocar as ordens jurídicas euclidianas soviéticas e nazistas, representadas pelo disco praticamente rígido (L), no sentido de que se afastassem de $(\mathrm{N})$, polo da separação, em direção à(S), polo da unificação. Desse movimento relativo de conjuntos normativos, podemos observar a formação sutil e pouco definida de uma sombra (L') no plano vinculado (E), com respeito à delimitação da competência estatal referente à nacionalidade e à proteção das pessoas vítimas das medidas, sem precedentes, referentes ao abuso do direito exclusivo dos estados em matérias de naturalização, expulsão, migração e desnacionalização, de um lado, e, de outro, referente ao costume calcado na cortesia internacional, decorrente da competência pessoal dos estados estrangeiros.

Em relação às fases da nomogênese do Estatuto do Refugiado, como fonte de direito internacional, Assis de Almeida relata-nos que, da perpectiva jurídica (1920-1935), a $\mathrm{SdN}$ teve de se ajustar à primeira onda maciça de apátridas, de nacionalidade russa, que

\footnotetext{
${ }^{40}$ LE FUR, Louis. Reconnaissance, Détermination et Signification en Droit international du Domaine Laissé par ce dernier à la Compétence Exclusive de l'État. Huitieme Commission. Travaux Préparatoires de la Session de Cambridge. In: Annuaire de 1'Institut de Droit International. 1931. p. 85.

41 ALMEIDA, Guilherme Assis de. A Proteção da Pessoa Humana no Direito Internacional: Conflitos Armados, Refugiados e Discriminação Racial. São Paulo: Editora CLA Cultural, 2018. p. 61.
} 
perderam a proteção do regime soviético por meio das primeiras desnacionalizações sem precedentes na história da humanidade. O movimento relativo da $\mathrm{SdN}$ em relação à competência exclusiva dos soviétivos foi o de regular o fluxo por meio da criação do Alto Comissariado para Refugiados Russos para avaliar o estatuto do refugiado russo. Posteriormente, a SdN reajustou-se ao, crescente, problema do refugiado, incorporando outros refugiados históricos, como armênios, assírios, turcos. Por fim, para procurar controlar a escalada da situação, a SdN criou (i) o Escritório Nansem para Refugiados, como forma de tratar juridicamente uma questão avaliada como coletiva, por meio da emissão de passaportes Nansem, e (ii) o Alto Comissariado para Refugiados oriundos da Alemanha em $1933 .^{42}$

Da perspectiva social (1935-1938), a comunidade internacional passava a sentir o influxo crescente de judeus de origem alemã como buscadores de asilo. Da avaliação da nova política nazista com relação à definição da nacionalidade alemã com base na raça, cujo suporte legal era o princípio das nacionalidades consagrados pelos Tratados de Paz, em torno de uma nação com língua, história, credo e sangue comuns, a $\mathrm{SdN}$ reajustou-se ao abuso da competência territorial e pessoal do regime nazista, na forma a regulamentá-la por intermédio da convocação de uma conferência de modo a ajustar a proteção dos refugiados judeus de origem alemã, por meio de uma fonte do direito: a Convenção relativa ao Estatuto do Refugiado provenientes da Alemanha.

Da perspectiva individualista (1938-1950), observamos uma iniciativa paralela à SdN, por meio da reação estadunidense ao problema dos refugiados. Trata-se de uma reação complementar e não excludente à ação institucional, na medida em que os EUA avaliaram que uma conferência no tradicional molde interestatal contribuiria para o equilíbrio pluralista de um problema jurídico ainda percebido como uma 'terra de ninguém' jurisdicional. Como um reajuste às práticas institucionais da $\mathrm{SdN}$, na conferência de Evian foi decidido pela regulação e controle do problema dos povos sem estado, por meio (i) de uma nova definição de refugiado em que se buscava garantir a proteção e assistência de pessoas nessa condição mesmo dentro do território dos países de origem e (ii) da criação de uma nova organização interestatal, Comitê Intergovernamental para Refugiados [CIR, 1938-1950], que passaria a avaliar o problema mediante os motivos fundados em opiniões 
políticas, crenças religiosas e origem racial, critérios esses vigentes até o presente com a positivação do Estatuto do Refugiado.

Apesar de a repartição das competências ser fixada juridicamente pelo Pacto da Sociedade das Nações e as sucedânias fontes e normativas internacionais, os conflitos de ordem política, como o problema das pessoas deslocadas, têm como característica a projeção de interesses e valores nacionais no plano das relações internacionais, o que determina a estrutura limitadada vinculação pelo direito, no caso da figura 2 em anexo, por analogia, tratamos de chamar de plano (E). O que percebemos, contudo,é a existência de sombras jurisdicionais ( $\left.\mathrm{L}^{\prime}\right)$ tendentes ao infinito, pouco definidas e pouco intensas, e muito alargadas, no plano (E), dado que, o movimento relativo entre as ordens jurídicas euclidianas (L) para a configuração de sombras (L') de leis decooperação não implicou afastamentos da fonte luminosa da soberania $(\mathrm{N})$, por isso, a interação entre os campos jurisdicionais com suporte na internacionalização da quarta marca da soberania resultou em conjuntos normativos cooperativos pouco vinculativos e da fraca regulação e controle pelo direito internacional, com respeito aos temas decorrentes do problema dos refugiados no sistema internacional, uma vez que ele está enredado em interesses políticos e jurídicos das soberanias.

$\mathrm{Na}$ Era da Catástrofe, os temas políticos referentes à realidade das pessoas deslocadas, sob a forma de refugiados, apátridas e minorias, atingem grandes proporções, na medida em que se tratava de temas jurisdicionalmente novos para a comunidade internacional.Sendo uma 'terra de ninguém,' na medida em que estava fora da competência exclusiva da Sociedade das Nações e pertenciam à 'vida íntima' dos estados soberanos, não haviaconsenso do direito comum positivado. Como vimos, as tentativas de delimitação da comunidade internacional com relação aos refugiados históricos não surtiram muito efeito em virtude da própria natureza da lei cooperativa internacional, que se baseia na razoabilidade e na boa-fé dos estados para que haja a comunhão de interesses diversos.

A precária posição do indivíduo no direito internacional manifesta-sepela condição de fragilidade da pessoa humana despojada de nacionalidade, ao ter frustrado seu vínculo mais direto com o estado-nação, fundado no valor-fonte da tradição jusnaturalista de que os direitos fundamentais são inalienáveis e inerentes à pessoa humana criada à imagem de Deus.Diante da impossibilidade de encontrar um novo lar, como Celso Lafer aponta inspirado na análise arendtiana sobre a crise dos direitos humanos, grandes massas de indivíduos expulsas da trindade estado-povo-território, inclusive e sobretudo, dos próprios 
estados perpetradores foram privadas de cidadania e destituídas do princípio da legalidade. ${ }^{43}$

O drama dos apátridas, das pessoas expulsas da trindade território-povo-estado, se apresentou como um dos antecedentes da ruptura do 'estado de natureza totalitário', concebido no seio das nações civilizadas, uma vez que esse contingente humano foi alvo das desnacionalizações em massa, expediente inédito e imprevisto para a época, dado que implicava renúncia da competência pessoal do estado. Como resultado dessa massa de povos sem estado, os campos de concentração, de trabalho forçado e de extermínio se configuraram como a instituição paradigmática da síncope dos direitos fundamentais e da cortesia internacional, ao gosto do arbítrio do tirano.Com a ruptura provocada pelo regime totalitário nazista em que 'tudo é possível', a condição de fragilidade do indivíduo, nacional e estrangeiro, desafiou as limitações do direito internacional à soberania, quando levadas à exasperação do exercício de sua soberania territorial em detrimento da competência pessoal estatal com relação à proteção da dignidade humana e da proteção internacional do homem, calcada no princípio da responsabilidade do governo por danos ao estrangeiro.

A experiência do 'estado de natureza totalitário' enganou e guiou milhões de pessoas inocentes para o 'massacre administrativo' nos campos de extermínio espalhados pelos principais centros geográficos da Europa centro-oriental, de forma a possibilitarem o deslocamento mais eficiente dos trens da morte, sob direção de Adolf Eichmann. Podemos, dedicar-lhes nossa reflexão final, de forma a situar os sistemas de referência relativos aos campos jurisdicionais e à ideia de soberania como energia, ao seguir o experimento mental de Einstein para o teste da simultaneidade e nos indagarmos a respeito da seguinte situação-limite: assim como um dos perpretadores nazistas esperando o desembarque de suas vítimas inocentes nos barrancos de Sobibór, Auschwitz-Birkenau, Treblinka ou Belzec, um dos milhões de deportados para os campos de concentração, dentro dos trens da morte em movimento, observa dois raios ao mesmo tempo? Com a revelação do princípio da relatividade da simultaneidade, concluiu Einstein que não.

Da perspectiva de nossa proposta acerca da soberania como uma forma de energia potential (raio), os pontos de vistas diferentes entre vítimas do Holocausto e criminosos internacionais dos direitos humanos observaram diferentes formas de interação das soberanias no plano internacional. Dessa forma, no rarefeito "espaço de liberdade, de 
segurança e justiça," conforme Delmas-Marty apresenta o processo de humanização do direito internacional por meio da existência de mecanismos que combinem cooperação e harmonização no campo penal, o III Reich exasperou a lógica de Lótus, ao liberar sua energia como uma reação ao 'Diktat' de Versalhes com base na ideia consciente, inspirada no princípio das nacionalidades dos Tratados de Paz. Da luta pela vitória da raça humana ariana, ao promover uma política de autoderminação da nação alemã tão extensa e desimpedida quanto as forças nazistas conseguiram agir sem forças contrárias que as limitassem para a configuração de seu 'espaço vital,'leva-nos a identificar que as forças da gravidade deslocaram a ordem totalitária mais perto de $(\mathrm{N})$, na figura 2 no anexo, cuja sombra do direito (L') tende a se dissipar ao infinito em razão daquilo que Lafer identificou como ruptura lógica do razoável da perspectiva da Filosofia do Direito. ${ }^{44}$

Da perspectiva das vítimas, o sistema de referência para essa situação-limite, cujo precedente foi criado e aplicado pelo regime totalitário nazista em relação aos seus próprios nacionais e em relação aos estrangeiros, foi visto longe de $(\mathrm{N})$ e perto de $(\mathrm{S})$, na figura 2 em anexo, uma vez que o pesadelo que elas experimentaram nos campos de concentração negou todo o plularismo, toda a diversidade humana, sob a forma daquilo que Assis de Almeida identifica como morte social, a perda de proteção do governo de forma sem precedentes por meio da privação dos direitos de cidadania. Esse fenômeno representou uma ruptura dos fundamentos jusnaturalistas dos direitos do homem, cuja fórmula estadunidense se fundamentava na criação do ser humano à imagem e semelhança de Deus, e na fórmula francesa dizia respeito às exigências da lei natural. ${ }^{45}$

Nas sombras do direito unificador e hegemônico, negador de todo respeito à diversidade humana e dos valores jurídicos fundamentais para a dignidade humana, queem nosso caso, localizamos perto de (S) na figura 2 no anexo, Arendt comenta que "o mundo não viu nada de sagrado na abstrata nudez de ser unicamente humano." Como uma reação desesperada com vistas a um mínimo de segurança na desordem nazista, as vítimas da Shoah buscaram no costume internacional da comitas gentium uma garantia coletiva para as suas condições de pessoas supérfluas, indejesáveis, por isso, a teórica política relata-nos como as vítimas se apegavam à sua nacionalidade como uma maldição do estado-nação, "como último vestígio da sua antiga cidadania, como o último laço remanescente e

\footnotetext{
${ }^{44}$ LAFER, Celso. A Reconstrução dos Direitos Humanos: um diálogo com o pensamento de Hannah Arendt. São Paulo: Companhia das Letras, 1988. p. 21.

45 ALMEIDA, Guilherme Assis de. A Proteção da Pessoa Humana no Direito Internacional: Conflitos Armados, Refugiados e Discriminação Racial. São Paulo: Editora CLA Cultural, 2018. p. 96.
} 
reconhecido que os ligaria à humanidade." ${ }^{46}$ Enquanto as vítimas experimentavam o pesadelo unificador hegemônico do regime totalitário nazista perto de (S) na figura 2, suas aspirações buscavam uma regra internacional que se havia fragmentado perto de $(\mathrm{N})$, à proporção que as ocupações do estado totalitário nazista execraram a igualdade da soberania entre países, bem como da incapacidade de os países invadidos reagirem soberanamente para exercerem sua competência pessoal ou renunciarem-na em favor dos ideiais nazistas de raça e extermínio das minorias.

Dessa inadequação da tradição revelada pelo 'estado de natureza totalitário,' em que se observa a quebra do valor-fonte da pessoa humana com a existência das pessoas deslocadas da trindade estado-povo-território, como os refugiados, apátridas e indivíduos pertencentes a minorias nos campos de concentração, trabalho forçado e extermínio, Arendt contempla a igualdade como uma ilusão inerente à condição humana, na medida em que não é um dado, mas um construído por meio da decisão conjunta dos homens em espaço público, o que demonstra um vínculo de indissolubilidade entre a comunidade e o indivíduo. Lafer, ao comentar a conclusão de Arendt sobre os direitos humanos como uma invenção humana, fruto da privação da cidadania em nível nacional e da nacionalidade em nível internacional e, por isso, expressão da revogação sub-reptícia do princípio da legalidade no exercício das competências territorial e pessoal dos estados-nações, sintetizaa contingência do valor da pessoa humana face à potencialidade do 'estado de natureza totalitário' como ameaça à preservação de um espaço público que permita a organização política da comunidade, tal como segue:

Com efeito, os direitos humanos enquanto conquista história e política, ou seja, uma invenção humana, estavam vinculados à solução de problemas de convivência coletiva dentro de uma comunidade política. É por isso que, no âmbito desta, o próprio cerceamento dos direitos humanos por força de lei não significa perder os benefícios da legalidade. [...] Desta reflexão sobre a fundamental importância do princípio da isonomia como critério de organização do Estado-nação, e de sua análise da condição dos apátridas, Hannah Arendt extrai a sua conclusão básica sobre os direitos humanos. Não é verdade que "todos os homens nascem livres e iguais em dignidade e direitos", como afirma o artigo $1^{\circ}$ da Declaração Universal de Direitos Humanos da ONU, de 1948, na esteira da Declaração de Virgínia de 1776 (artigo $1^{\circ}$ ), ou da Declaração Francesa de $1789\left(\operatorname{artigo} 1^{\circ}\right)$. Nós não nascemos iguais: nós nos tornamos iguais como membros de uma coletividade em virtude de uma decisão conjunta que garante a todos direitos iguais. A igualdade não é um dado - ele não é uma physis, nem resulta de um absoluto transcendente externo à comunidade política. Ela é um construído, elaborado convencionalmente pela ação conjunta dos homens através da organização da comunidade política. Daí a indissolubilidade da relação entre

46 ARENDT, Hannah. Origens do Totalitarismo. Tradução Roberto Raposo. 5 ${ }^{\text {a }}$ reimpr. São Paulo: Companhia das Letras, 2012. p. 333. 
o direito individual do cidadão de autodeterminar-se politicamente, em conjunto com seus concidadãos, através do exercício de seus direitos políticos, e o direito da comunidade de autodeterminar-se, construindo convencionalmente a igualdade. ${ }^{47}$

Os problemas políticos do 'estado de natureza totalitário' projetados para o plano internacional, como na existência maciça das pessoas deslocadas, realçaram a necessidade de colaboração internacional com vistas à formação de um consenso que permitisse o estabelecimento de garantias normativas e institucionais com abrangência internacional.Os direitos humanos concebidos por meio de um esforço notável da comunidade internacional e, por isso, tidos como uma conquista histórica, política e jurídica da civilização, com base no processo de generalização de valores, conforme aponta Hans Joas, ao transcenderem as ordens jurídicas euclidianas fundadas em nível nacional por meio de um alcance universal, manifestam-se por intermédio da criação de lei internacional, como o mais expressivo reconhecimento internacional de uma nova narrativa calcada na dignidade universal da pessoa humana. ${ }^{48}$ Assis de Almeida, por sua vez, identifica que essa nova narrativa renovou o valor dezenovesco da sacralidade da pessoa, uma vez que a característica personalista da Declaração Universal de Direitos Humanos de 1948 promoveu uma diferenciação com relação ao tradicional valor-fonte jusnaturalista relativo ao indivíduo autônomo. Nesse sentido, de acordo com o jurista, enquanto dois terços da declaração são destinados à dignidade da pessoa humana em sua característica relacional a outros indivíduos e instituições, o direito à nacionalidade é resguardado como um caso de direito individual, o que o leva a apontar que a "Declaração Universal dos Direitos Humanos de 1948 foi o primeiro instrumento jurídico da comunidade internacional a dirigir-se aos Estados e aos indivíduos."49

O reconhecimento da pessoa no processo de humanização do direito internacional demonstra o fenômeno jurídico da relativização da soberania estatal em mais uma perspectiva, na medida em que, o monopólio legislativo dos estados na forma da prática do desdobramento funcional foi relativizado em favor de todas as pessoas humanas como sujeitos de direito internacional universalmente reconhecidos e legitimados, como uma condição para o exercício dos direitos humanos individuais e coletivos, nosentido de

\footnotetext{
${ }^{47}$ LAFER, Celso. A Reconstrução dos Direitos Humanos: um diálogo com o pensamento de Hannah Arendt. São Paulo: Companhia das Letras, 1988. p. 147; 150.

48 JOAS, Hans. A Sacralidade da Pessoa: Nova Genealogia dos Direitos Humanos. Tradução Nélio Schneider. São Paulo: Editora Unesp. 2012.

49 ALMEIDA, Guilherme Assis de. A Proteção da Pessoa Humana no Direito Internacional: Conflitos Armados, Refugiados e Discriminação Racial. São Paulo: Editora CLA Cultural, 2018. p. 85/90.
} 
apresentarem reivindicações quanto à dignidade humana e à proteção internacional dos interesses fundamentais do homem.Além desses direitos, responsibilidades penais individuais por atos que provocam espanto nos valores comunitários podem ser imputadas com, com base nos princípios de Nuremberg.Independentemente do princípio da obediência devida e da imunidade funcional dos chefes e burocratas do estado sob a guarida das imunidades de execução e de jurisdição, aderimos, em gênero, número e grau à tese de Perrone-Moisés acerca do prevalecimento dos interesses da comunidade internacional em detrimento da soberania dos representantes estatais, quando identificado a existência de crimes internacionais dos direitos humanos.A impunidade dá azo, ao fenômeno que Arendt e Lafer refletiram sobre as origens do totalitarismo, na medida em que significa uma negação da diversidade humana e do acesso ao espaço público como uma forma de se garantir que a igualdade humana se realize por intermédio das instituições. ${ }^{50}$

Finalizamos essa tese com um alerta a respeito dos direitos humanos como invençãoconsciente capaz de liberar as energias potenciais da soberania, na medida em que, não obstante as normas internacionais de direitos humanos reconhecerem a proteção e a dignidade humana como valores a serem respeitados, cultivados e protegidos, esse consenso em torno dessa invenção está sujeito à oscilação da opinião pública e das ações de governos e corporações, muitas vezes isentas de responsabilidades internacionais como um vestígio da obstinada concepção de soberania absoluta na forma de defesa da propriedade privada transnacionalmente. Por isso afirmamos a necessidade de se prezar pela dignidade humana em todos os níveis e interações dos sistemas normativos, pois, no limite, a defesa da soberania em detrimento dos seres humanos configura uma realidade perturbadora apontada por Boaventura de Souza dos Santos segundo a qual "a grande maioria da população mundial não é sujeito de direitos humanos. É objeto de discursos de direitos humanos." 51

Para nós, em vista desse estudo do mapeamento da soberania como um valor diretor do direito internacional sob a forma de um feixe de luz, de energia potencial, identificamos que o dilema referente à soberania e aos direitos humanos é ilusório, no sentido de que a violação dos direitos humanos, em geral, e dos crimes internacionais, em particular,

${ }^{50}$ PERRONE-MOISÉS, Cláudia. Direito Internacional Penal: imunidades e anistias. Barueri: Manole, 2012.

51 SANTOS, Boaventura de Souza. Direitos Humanos: Ilusões e Desafios. In: Direitos Humanos, Democracia e Desenvolvimento. São Paulo: Cortez. 2012. p. 42. 
destroem a fonte do poder soberano, qual seja a energia provinda da vontade das pessoas. Como uma energia potencial oriunda do poder da mente, a fonte da soberania origina-se da massa de indivíduos pertencentes ao estado nacional, por isso, concluímos com a citação de um príncipe que renunciou, conscientemente, à arte da guerra em benefício da libertação da mente humana e, por extensão, da humanidade. Ao examinar o mundo com os olhos de um ser humano que alcançou a iluminação e viu seres ardendo com muitas febres, com o fogo da cobiça, da raiva e da delusão, Buda assim declara sobre o mundo:

O mundo está em chamas.\ Afligido pelo contato,nomeia a doença - “eu”.\Pois qualquer que seja a concepção,o fato é sempre distinto desta.\ [...] Olhem para o mundo,os seres atormentados pela ignorâncianão estão libertosdo deleite por aquilo que é/existe. $\$ Todos os tipos de ser/existir,em qualquer lugar,de qualquer modo,são impermanentes,sujeitos ao sofrimento, cuja natureza é a mudança. ${ }^{52}$

${ }^{52}$ BUDA. Loka Sutta. O Mundo. In: Udana III. 10

Disponível em: http://www.acessoaoinsight.net/sutta/UdIII10.php Acesso em: 10\01\2020. 



\section{REFERÊNCIAS}

Acta Pacis Westphalicae. In: Die Westfälischen Friedensverträge vom 24. Oktober 1648. Texte und Übersetzungen(Supplementa electronica,1)Disponível em: (URL: http://www.pax-westphalica.de/ipmipo/).

AGNEW, John. Globalization and Sovereignty. United Kingdom: Rowman \& Littlefield Publishing Group. 2009.

ALMEIDA, Guilherme Assis de. A proteção da pessoa humana no direito internacional: conflitos armados, refugiados e discriminação racial. São Paulo: Editora CLA Cultural, 2018.

AMARAL, Sylvino Gurgel do. Ensaios sobre a Vida e Obras de Hugo Grotius. Rio de Janeiro: Garnier, 1903.

.GRÓCIO, Hugo. Mare Liberum (1609).In: Ensaios sobre a Vida e Obras de Hugo Grotius. Rio de Janeiro: Garnier, 1903.

ARENDT, Hannah. Origens do Totalitarismo. Tradução Roberto Raposo. $5^{\text {a }}$ reimpr. São Paulo: Companhia das Letras, 2012.

.O que é autoridade?In:Entre o Passado e o Futuro.Tradução Mauro W.

Barbosa. São Paulo: Perspectiva, $7^{\mathrm{a}}$ ed., $2^{\mathrm{a}}$ reimpressão, 2014.

ARISTÓTELES. Ética A Nicômaco.Trad. Luciano Ferreira de Souza. São Paulo: Martin Claret. 2004. Livro V.

BARTELSON, Jens. A Genealogy of Sovereignty. London: Cambridge University Press, (Cambridge Studies in international relations: 39), 1995

BLOCH, Marc. Os Reis Taumaturgos. O Caráter Sobrenatural do Poder Régio França e Inglaterra.Tradução: Júlia Mainardi.São Paulo: Cia das Letras.1924(1993).

BOBBIO, Norberto. Estado, governo, sociedade: por uma teoria geral da política. Tradução Marcos Aurélio Nogueira, RJ: Paz e Terra, 1987.

. Thomas Hobbes. tradução de Carlos Nélson Coutinho. $5^{\text {a }}$ ed., Rio de Janeiro: Campus, 1991.

BOBBIO, Norberto; MATTEUCCI, Nicola; PASQUINO, Gianfranco. Dicionário de Política. trad. Carmen C., Varriale et ai; Brasília: Editora Universidade de Brasília, $11^{\text {a }}$ ed., vol.1, 1998.

BODIN, Jean. Os Seis Livros da República: Livro Primeiro. Trad. Carlos Orsi Morel. 1. ed., São Paulo: Editora Ícone, 2011. Coleção Fundamentos do Direito. 
BURNS, Edward Mcnall. História da Civilização Ocidental. Tradução. Lourival Gomes Machado, Lourdes Santos Machado e Leonel Vallandro.V.1. 3ed. Porto Alegre: Editora Globo.

CASELLA, Paulo Borba. Fundamentos do Direito Internacional Pós-Moderno. SP: Quartier Latin, 2008.

. Direito Internacional dos Espaços. São Paulo: Editora Atlas. 2009.

.Direito Internacional no Tempo Medieval e Moderno até Vitória.São

Paulo: Editora Atlas, 2012.

Direito Internacional no Tempo Moderno de Suarez a Grócio. São Paulo: Atlas, 2014.

Direito Internacional no Tempo Clássico. São Paulo: Atlas, 2015.

CHEVALliER, Jean-Jacques. As Grandes Obras Políticas de Maquiavel a nossos dias. Tradução Lydia Cristina. Rio de Janeiro: Agir, 2001. 8.ed./3.impr.,

COSTA, Wanderley Messias da. Geografia Política e Geopolítica: Discursos sobre o Território e o Poder. 2.ed., 3.reimpr. São Paulo: Editora da Universidade de São Paulo. 2016.

C.P.J.I., Affaire du Vapeur Lotus. Série A, Arrêt nº10, du 7/09/1927. Disponível em: https://www.icj-cij.org/en/pcij-series-a

Arrêt Mavrommatis,Série A, Arrêt $\mathrm{n}^{\circ} 2$, 1924. Disponível em: https://www.icj-cij.org/en/pcij-series-a

Décrets de Nationalité Promulgués en Tunisie et au Maroc. Avis Consultif. Série B., $\mathrm{n}^{\circ} 4$, p. 24..Disponível em: https://www.icj-cij.org/fr/cpji-serie-b

DAUDIN, Pascal. The Thrity Years'War: The First Modern War?Humanitarian Law \& Policy. (2017) Disponível em:

< http://blogs.icrc.org/law-and-policy/2017/05/23/thirty-years-war-first-modern-war/ >

DELMAS-MARTY, Mireille. Un Pluralisme Ordonné. In: Études Juridiques Comparatives et Internationalisation du Droit. Paris, 2006. Disponível em:https://www.college-de-france.fr/media/mireille-delmas-

marty/UPL12910_r_sum_cours0405.pdf

NGUYEN QUOC, Dinh; PELLET, Alain; DAILLIER, Patrick. Direito Internacional Público. Tradução Vítor Marques Coelho. $2^{\mathrm{a}}$ ed., Lisboa: Fundação Calouste Gulbenkian. 2003.

EINSTEIN, Albert. Über Einen die Erzeugung und Verwandlung des Lichtes betreffenden Heuristischen Gesichtspunkt. In: Annalen der Physik. 17. 1905. p. 132/48. 
. Über die von der molekularkinetischen Theorie der Wärme geforderte Bewegung von in ruhenden Flüssigkeiten suspendierten Teilchen. In: Annalen der Physik. 17. 1905. p. 549-560.

. Zur Elektrodynamik bewegter Körper. In: Annalen der Physik. 17. 1905. p. 891/921.

Ist die Trägheit eines Körpers von seinem Energieinhalt abhängig?In: Annalen der Physik. 17. 1905.

. Relativity: The Special and General Theory. Trad. Robert W. Lawson.

3. ed. University of Sheffield. 1920.

. Geometry and Experience. An Expanded Form of an Address to the Prussian Acaddemy of Sciences in Berlim on January 27th, 1921. In:Sidelights on Relativity. Trad.G.B. Jeffery and W. Perrett. 3. ed. University of Sheffield. 1922.

FONSECA, José Roberto Franco da. O Caso Clássico do Navio Lótus à Luz da Ciência Moderna. Revista da Faculdade de Direito. v.90. 1995.

FRIEDMANN, Wolfgang. Mudança da Estrutura do Direito Internacional. Tradução A.S. Araújo. Rio de Janeiro: Livraria Freitas Bastos S.A., 1971.

GESTEIRA, Heloísa Meireles. Da Liberdade dos Mares: Guerra e Comércio na Expansão Neerlandesa para o Atlântico. Revista de História USP, São Paulo, v.154, 2006.

GRÓCIO, Hugo. O Direito da Guerra e da Paz. Tradução Ciro Mioranza. Ijuí: Editora Unijuí. 2 ed., 2004.V.I. (Coleção clássicos do direito internacional/ coord.Arno dal Ri Júnior).

HARARI, Yuval. Sapiens - Uma Breve História da Humanidade. Tradução: Janaína Marcoantonio. 26ed. Porto Alegre, RS:L\&PM, 2017.

HERZ, John. "Idealist Internationalism and the Security Dilemma". World Politics, v.2, n.2. p.157-180.

Political Realism and Political Idealism: A Study in Theories and Realities.Chicago: Chicago University Press, 1951.

HOBBES, Thomas. Leviatã ou Matéria, Forma e Poder de um Estado Eclesiástico e Civil. Organizado por Richard Tuck; edição brasileira supervisionada por Eunice Ostrenky. Tradução João Paulo Monteiro, Maria Beatriz Nizza da Silva. 2a ed. São Paulo: Martins Fontes, 2008. (Clássicos Cambridge de filosofia política). 
HOBSBAWN, Eric. Nações e Nacionalismo desde 1780: Programa, Mito e Realidade. Tradução: Maria Celia Paoli, Anna Maria Quirino. Rio de Janeiro: Paz e Terra. 1990.

Era dos Extremos: o Breve Século XX: 1914-1991. Tradução Marcos Santarrita. São Paulo: Companhia das Letras, 1995.

HOLlandA, Sérgio Buarque. Visão do Paraíso. Os Motivos Edênicos no Descobrimento e Colonização do Brasil.São Paulo: Brasiliense, 1996.

JOAS, Hans. A Sacralidade da Pessoa: Nova Genealogia dos Direitos Humanos. Tradução Nélio Schneider. São Paulo: Editora Unesp. 2012.

KLEFFENS, Eelco Nicolas van, Sovereignty in Internacional Law: Five Lectures. V.082. In: Collected Courses of the Hague Academy of International Law.

LAFER, Celso. A Reconstrução dos Direitos Humanos: um diálogo com o pensamento de Hannah Arendt. São Paulo: Companhia das Letras, 1988.

Hannah Arendt: pensamento, persuasão e poder. Rio de Janeiro: Paz e Terra, 1979. (Coleção o Mundo hoje; v.35).

A Internacionalização dos Direitos Humanos. Constituição, Racismo e Relações Internacionais. Barueri: Manole, 2005.

LE FUR, Louis. Reconnaissance, Détermination et Signification en Droit international du Domaine Laissé par ce dernier à la Compétence Exclusive de l'État. Huitieme Commission. Travaux Préparatoires de la Session de Cambridge. In: Annuaire de 1'Institut de Droit International. 1931.

LIMA, Lucas Carlos. O Surgimento da Corte Permanente de Justiça Internacional: Formação Europeia e Fundamento Voluntarista. In: Revista Eletrônica do Curso de Direito da UFSM. v.8, n.1. 2013.

MAIRET, Gérard. Le Principe de Souveraineté. Histoires et Fondements du Povoir Moderne.Paris: Éditions Gallimard, 1997.

MACHADO, Lia Osório. Sistemas, Fronteiras e Território. Rio de Janeiro: Grupo Retis/UFRJ. Departamento Geografia, 2002.

MAQUIAVEL, Nicolau. O Príncipe.Tradução Maurício Santana Dias, Peguin Companhia, 1513 (2010).

MELLO, Celso D. de Albuquerque. Curso de Direito Internacional Público. 14 ed. Rio de Janeiro: Renovar, 2002.

MOREIRA LIMA, Sérgio Eduardo. Privilégios e Imunidades Diplomáticos. Brasília: Instituto Rio Branco: Fundação Alexandre de Gusmão, 2002. 
PELLET, Alain. Lótus, Quantos Despropósitos São Proferidos em teu Nome! Considerações sobre o conceito de soberania na jurisprudência da Corte Mundial. Trad. Eraldo Silva Júnior. Rio de Janeiro: Revista Publicum,v.3. n.1, 2017.

PERRONE-MOISÉS, Cláudia. Direito Internacional Penal: imunidades e anistias. Barueri: Manole, 2012.

RADNITZKY. Ernst. Zur Lehre von der Treupflicht im Dientverhältnisse. Archiv für ÖffentlichesRecht, v. 20. n. 1. 1906.

Die Rechtliche Natur des Staatsgebiets. Archiv für ÖffentlichesRecht, v. 20. n. 3. 1906.

Meeresfreiheit und Meeresgemeinshaft. Archiv für ÖffentlichesRecht, v. 22. n. 3/4. 1907. arts. cits., tb. publ. no Oesterreichische Zeitschrift für ÖffentlichesRecht, III, 1917.

RICOEUR, Paul. Quem é o Sujeito de Direito? In: O Justo 1: A Justiça como Regra Moral e como Instituição. Tradução Ivone C. Benedetti. São Paulo: WMF Martins Fontes, 2008

.O Justo 2: Justiça e Verdade e Outros Estudos. São Paulo: WMF Martins Fontes, 2008.

SANTOS, Boaventura de Souza. Direitos Humanos: Ilusões e Desafios. In: Direitos Humanos, Democracia e Desenvolvimento. São Paulo: Cortez. 2012.

SCELLE, George. Règles Générales du Droit de la Paix. RCADI. IV. vol. 46. 1933.

SCHOENBORN, Walter. La Nature Juridique du Territoire. RCADI. 1929. t.30. SPITZ, Jean-Fabien. Bodin et la Souveraineté. Paris: PUF, 1998.

STACHEL, John. 1905 e Tudo o Mais. In Revista Brasileira de Ensino de Física, v. 27. n.1.2004.

STEIGER, Heinhard. From the International Law of Christianity to the International Law of the World Citizen. Reflections on the Formation of the Epochs of the History of International Law. Journal of History of International Law, vol. 3, $\mathrm{n}^{\circ}$, 2001 .

TELLES JUNIOR, Goffredo. Direito Quântico: ensaio sobre o fundamento da ordem jurídica.9. ed., São Paulo: Saraiva, 2014.

TERNON, Yves. Genèse du droit international. Des Pères fondateurs aux conférences de la Haye.Paris: Éditions Karthala, 2016. 
TURRETTINI, Robert.La Signification des Traités de Westphalie dans le Domaine du Droit des Gens.Thèse $\mathrm{n}^{\circ} 460$ (Faculté de Droit) - Université de Genéve.Genéve: Imprimerie Genevoise. 1949.

VERDROSS, Alfred. Règles Générales du Droit Internacional de la Paix.RCADI, 1929, t.30.

WENDT, Alexander. Anarchy is what states make of it: the social construction of power politics. International Organization 46, 1992.

DINSTEIN, Yoram. Interaction Between Treaty and CustomsIn: Collected Courses of the Hague Academy of International Law, The Hague Academy of International Law, (Vol.322), 2007. 
ANEXO
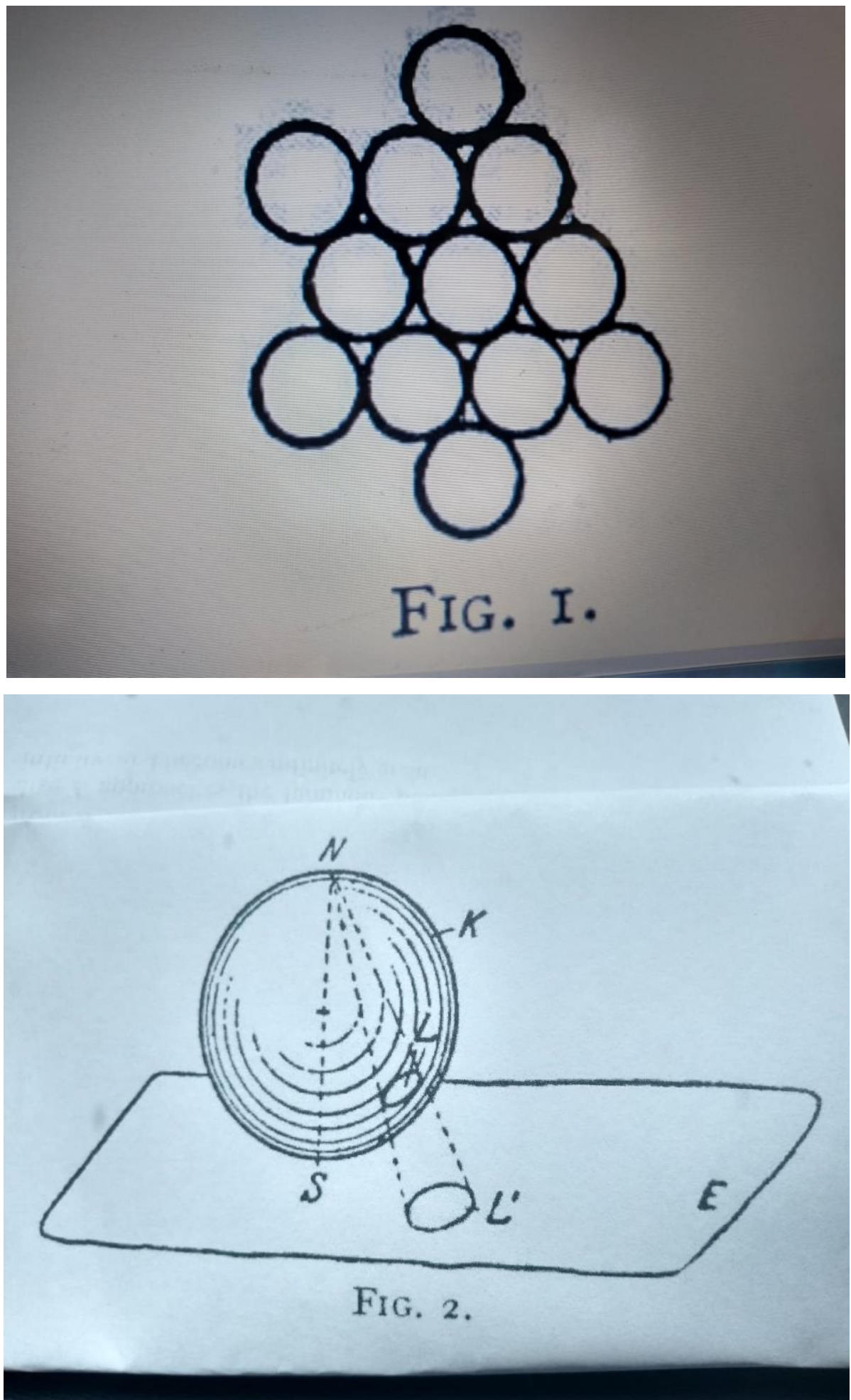

${ }^{1}$ EINSTEIN, Albert. Geometry and Experience. An Expanded Form of an Address to the Prussian Acaddemy of Sciences in Berlim on January 27th, 1921. In: Sidelights on Relativity. Trad.G.B. Jeffery and W. Perrett. 3. ed. University of Sheffield. 1922. Anex. p. 25; 26, respectivamente. 